\title{
Improvement of Salinity Stress Tolerance in Rice: Challenges and Opportunities
}

\author{
Thi My Linh Hoang ${ }^{1}$, Thach Ngoc Tran ${ }^{2}$, Thuy Kieu Tien Nguyen ${ }^{2}$, Brett Williams ${ }^{1}$, \\ Penelope Wurm ${ }^{3}$, Sean Bellairs ${ }^{3}$ and Sagadevan Mundree ${ }^{1, *}$ \\ 1 Queensland University of Technology (QUT) Centre for Tropical Crops and Biocommodities, Brisbane, \\ QLD 4001, Australia; lt.hoang@qut.edu.au (T.M.L.H.); b.williams@qut.edu.au (B.W.) \\ 2 Cuu Long Delta Rice Research Institute, Can Tho, Vietnam; thach69@gmail.com (T.N.T.); \\ ntktien10@gmail.com (T.K.T.N.) \\ 3 Research Institute for Environment and Livelihoods, Charles Darwin University, Darwin 0909, Australia; \\ penny.purm@cdu.edu.au (P.W.); sean.bellairs@cdu.edu.au (S.B.) \\ * Correspondence: Sagadevan.mundree@qut.edu.au; Tel.: +61-731-388-386
}

Academic Editors: Matthew Gilliham and Peter Langridge

Received: 2 September 2016; Accepted: 25 October 2016; Published: 31 October 2016

\begin{abstract}
Rice (Oryza sativa L.) is an important staple crop that feeds more than one half of the world's population and is the model system for monocotyledonous plants. However, rice is very sensitive to salinity and is the most salt sensitive cereal crop with a threshold of $3 \mathrm{dSm}^{-1}$ for most cultivated varieties. Despite many attempts using different strategies to improve salinity tolerance in rice, the achievements so far are quite modest. This review aims to discuss challenges that hinder the improvement of salinity stress tolerance in rice as well as potential opportunities for enhancing salinity stress tolerance in this important crop.
\end{abstract}

Keywords: salinity; rice; salt tolerance; wild rice; genetic engineering; conventional breeding; MAS

\section{Introduction}

Salinity is a general term used to describe the presence of elevated levels of different salts such as sodium chloride, magnesium and calcium sulphates and bicarbonates in soil and water [1]. With more than 830 million hectares (ha) of salt-affected land globally [2,3] (Figure 1) and approximately two million ha of land uncultivable due to excessive salinity added each year [4], salinity is a growing worldwide problem. Salinity can develop naturally. However, human intervention has disturbed natural ecosystems, changed the hydrology of the landscape and significantly accelerated the salinisation of waterways and land. Irrigation and extensive clearing of vegetation, which bring the groundwater with soluble salts to, or close to, the soil surface, are the two major human activities that accelerate salinity. Of the 230 million ha of the world's irrigated land, 45 million ha (20\%) has been salt-affected [3]. When growing on salt-affected soils, crops must compete with salts in the soils for water as well as to cope with ion toxification, nutritional disorders and poor soil physical conditions to survive, therefore, their productivity was reduced [5,6]. By 2050, the world's population is predicted to reach 9.6 billion people and food production needs to increase approximately $70 \%$ by 2050 or 44 million metric tons annually to provide sufficient food for this population [7-9]. This is a challenge because there is very little potential for future expansion of arable lands, whereas environmental stresses affecting crop production are increasing [10-12]. Salinity and water deficit were listed as the two most critical factors that limit global crop production [13]. To help sustain the increasing population, crops with enhanced salinity tolerance must be developed to increase productivity on salt-affected lands. 


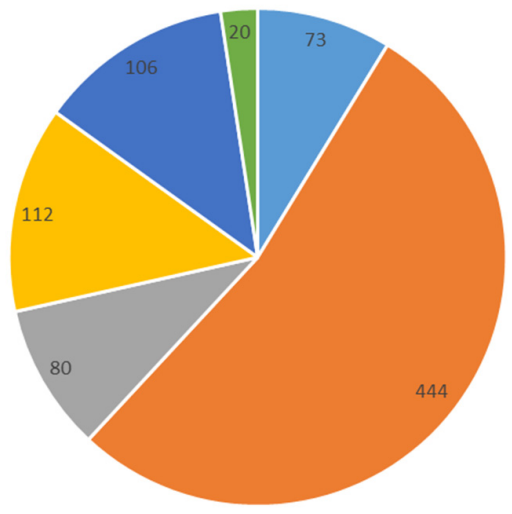

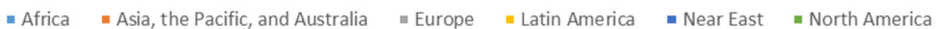

Figure 1. Global distribution of salt-affected soil (million ha).

Rice, one of the most important staple crops, feeds more than one half of the world's population. It is a member of the genus Oryza in the Family Poaceae. The Oryza genus has many species, of which two-Oryza sativa L. and O. glaberrima Steud-are cultivated. Oryza sativa is most commonly grown in Asia while O. glaberrima is native to West and central Africa [14,15]. Rice is cultivated in 114 of the 193 countries over the world in six continents, Asia, Africa, Australia, Europe, Latin America and North America [16]. In humid and sub-humid Asia, rice is the single most important source of employment and income for rural people, and it provides $50 \%-80 \%$ of the calories consumed for more than three billion Asians $[17,18]$. However, rice is very sensitive to salinity stress and is currently listed as the most salt sensitive cereal crop with a threshold of $3 \mathrm{dSm}^{-1}$ for most cultivated varieties [19], whereas, generally, a soil is only considered saline (salt-affected) if it has an $\mathrm{EC}_{\mathrm{e}}$ (electrical conductivity of its saturation extract) above $4 \mathrm{dSm}^{-1}$ [20]. Even at $\mathrm{EC}_{\mathrm{e}}$ as low as $3.5 \mathrm{dSm}^{-1}$, rice loses about $10 \%$ of its yield, and 50\% yield loss was recorded for rice at $\mathrm{EC}_{\mathrm{e}} 7.2 \mathrm{dSm}^{-1}$ [4]. Asia accounts for $90 \%$ of the world's production and consumption of rice $[16,18]$ but "Sea-level rise is already increasing rice-killing salinity in the deltas of Asian rivers, the richest rice-growing areas of the world" [21]. Therefore, it is crucial to enhance rice tolerance to salinity stress to enable this staple crop to provide enough food for rice-consuming communities. Although some success has been reported for enhanced salinity stress tolerance in rice, the achievements so far are quite modest. This review will discuss challenges that hinder the success of the improvement of salinity stress tolerance in rice and identify potential opportunities for enhancing salinity stress tolerance in this important crop.

\section{Rice Response to Salinity Stress}

In terms of responses to salinity stress, plants can be divided into two groups-halophyte or glycophyte-based on their level of salinity tolerance. Halophytes are plants that tolerate relatively high salt concentrations $(400 \mathrm{mM} \mathrm{NaCl})$, while glycophytes tolerate low concentrations [22]. Most crops are glycophytes and their growth is retarded during salinity stress. Among the cereals, rye (Secale cereale) is the most tolerant (threshold of $11 \mathrm{dSm}^{-1}$ ) and rice is the most sensitive crop plant with a threshold of $3 \mathrm{dSm}^{-1}$ for most cultivated varieties [19].

Rice has been reported to be relatively tolerant to salinity stress during germination, active tillering and towards maturity, but sensitive during early seedling and reproductive stages [23,24]. An addition of as little as $50 \mathrm{mM} \mathrm{NaCl}$ in the soil can reduce rice yield significantly [25]. Generally, salinity causes two types of stresses on plants: osmotic and ionic stresses. Osmotic stress occurs after the concentration of salts around the roots of the plant increase beyond a threshold tolerance level while 
ionic stress occurs when the concentration of salt in old leaves reaches a toxic level due to the influx of large amounts of $\mathrm{Na}^{+}$into the plant, resulting in increased $\mathrm{Na}^{+}$concentrations in the vacuole and cytoplasm leading to interruption of metabolic processes and cell death [6]. Like most plants, rice has evolved various mechanisms to cope with salinity stress including: (i) biosynthesis and accumulation of osmolytes for osmoprotection; (ii) ion homeostasis and compartmentation; (iii) antioxidants-ROS detoxification; and (iv) programmed cell death.

\subsection{Biosynthesis and Accumulation of Organic Osmolytes}

Organic osmolytes are small solutes that are used by cells to maintain cell volume under water stress. There are four major chemical categories of organic osmolytes: (i) small carbohydrates including sugars (e.g., trehalose), polyols (glycerol, inositols, sorbitol, etc.) and derivatives; (ii) amino acids (such as glycine, proline, taurine, etc.) and derivatives; (iii) methylamines (such as glycine betaine) and methylsulphonium solutes including dimethylsulphonopropionate (DMSP); and (iv) urea [26]. In an environment that has osmotic concentration changes, these osmolytes can be up- or down-regulated to prevent osmotic shrinkage in many species [26]. The first phase of salinity stress on plants is osmotic stress caused by excess salts outside the roots which affects plant growth immediately [6,27]. In low salt environments, plant cells can take up water and nutrients from the soil solution to support higher osmotic pressures compared to that of the soil solution. However, in high salt environments, the osmotic pressure of the soil exceeds that of plant cells (osmotic stress) and reduces the ability of plants cells to take up soil water and minerals [28]. To cope with osmotic stress, plant cells need to adjust their osmotic potential by accumulation of organic and/or compatible osmolytes. Garcia et al. [29] found that under salinity stress rice accumulates trehalose and that at low to moderate concentrations, trehalose reduces $\mathrm{Na}^{+}$accumulation, salT (an osmotically regulated gene) expression, and growth inhibition. At higher concentrations, trehalose can prevent $\mathrm{NaCl}$-induced loss of chlorophyll in blades, preserve root integrity, and enhance rice growth. A salt tolerant rice cultivar was reported to accumulate more proline during salinity stress compared to salt sensitive rice cultivar $[30,31]$. Proline is thought to play an essential role as an osmoregulator in plants exposed to hyperosmotic stresses such as drought and salinity [32]. Under stress condition, proline appears to be the most widely distributed osmolyte accumulated in organisms ranging from eubacteria to plants [32]. Glycine betaine, a quaternary ammonium compound that occurs naturally in a wide range of plants, animals and microorganisms [33] is also a very effective compatible solute [34,35]. Although rice plants do not accumulate glycine betaine endogenously, Harinasut and co-workers [36] found that rice plants can uptake exogenous glycine betaine and accumulate it in leaves to help the plants to maintain quantum yield of PSII during salinity stress.

\subsection{Ion Homeostasis and Compartmentation}

During salinity stress, increased extracellular $\mathrm{Na}^{+}$concentrations create a large electrochemical gradient that favours the passive transport of $\mathrm{Na}^{+}$into the cell through $\mathrm{K}^{+}$transporters, resulting in high cytosolic $\mathrm{Na}^{+}$concentration [37]. The influx of large amounts of $\mathrm{Na}^{+}$into the plant, when exposed to salinity stress, increases the intracellular $\mathrm{Na}^{+}$content, which results in deleterious effects by competing with $\mathrm{K}^{+}$in enzyme activation and protein biosynthesis [38,39]. One of the mechanisms that plants employ to tolerate salinity stress is to exclude $\mathrm{Na}^{+}$uptake by roots thereby maintaining low concentrations of $\mathrm{Na}^{+}$in the leaves. A failure in $\mathrm{Na}^{+}$exclusion manifests its toxic effect after days or weeks and causes premature death of older leaves [6]. $\mathrm{Na}^{+}$concentration in the leaves of rice is correlated to the level of salinity stress tolerance in both Indica and Japonica varieties [40]. Several studies have suggested that a low cytosolic $\mathrm{Na}^{+} / \mathrm{K}^{+}$ratio is required to maintain a favourable ionic homeostasis in plant cells under salinity stress condition [41,42] and that a low $\mathrm{Na}^{+} / \mathrm{K}^{+}$ratio improves photosynthesis and overall plant growth [43]. Wang et al. [44] reported that under salinity stress, genes related to sodium transport from roots to shoot such as OsHKT1;1, OsHAK10 and OsHAK16 were upregulated in the old leaves of rice. Meanwhile genes involved in facilitating $\mathrm{Na}^{+}$ 
exclusion from root xylem vessels to reduce shoot accumulation, like OsHKT1;5 and OsSOS1, were downregulated, leading to high concentrations of $\mathrm{Na}^{+}$accumulated in old leaves compared to young leaves. During salinity stress, salinity tolerant rice cultivars accumulate less $\mathrm{Na}^{+}$in leaves and shoots compared to salinity sensitive rice cultivars [40,45-47]. Salt tolerant rice cultivar Pokkali was reported to be able to reduce the uptake of $\mathrm{Na}^{+}$into cytosol and maintain a low cytosolic $\mathrm{Na}^{+}$by transient uptake of $\mathrm{Na}^{+}$into cytoplasm and fast extrusion of $\mathrm{Na}^{+}$into vacuoles, while the salt sensitive rice cultivar BRRI Dhan29 failed to do so [48].

\subsection{Antioxidants-ROS Detoxification}

Reactive oxygen species (ROS) are versatile molecules playing dual roles as both toxic compounds and signal transduction molecules that mediate responses to environmental stresses, pathogen infection, developmental stimuli and even programmed cell death in plants [49,50]. If left unchecked, copious ROS production can cause protein denaturation, mutation of DNA and peroxidation of lipids [51]. ROS levels have been reported to increase, causing significant injury and eventual death in plants during salinity stress [52-54]. In order to protect the cell from oxidative injury, plants have evolved a complex antioxidant defence system to scavenge and detoxify ROS [55-57]. Salt tolerant rice cultivar Pokkali was reported to have higher activity of ROS scavenging enzymes such as catalase (CAT) and enhanced levels of antioxidants including ascorbate (ASC) and glutathione (GSH), compared to the salt sensitive rice cultivar (Pusa Basmati) during salinity stress. A concerted action of both enzymatic and non-enzymatic ROS scavenging machineries is vital to overcome salinity-induced oxidative stress in rice [51]. Dionisio-sese et al. [58] reported that salt tolerant rice varieties display protection mechanisms against increased radical production during salinity stress by maintaining the specific activity of antioxidant enzymes.

\subsection{Programmed Cell Death (PCD)}

Being sessile, plants are particularly vulnerable to aberrant environmental conditions including saline soils and water deficit. To mitigate salinity stress, plants implement a range of strategies. However, if these mechanisms are unable to cope with the increased stress, the plant will implement PCD as a last ditch effort to survive $[59,60]$. Programmed cell death is a physiological and genetically controlled process that is evolutionarily conserved across kingdoms and allows multicellular organisms to eliminate excessive or damaged cells which arise during development and in response to abiotic and biotic stress [61,62]. Alongside cell division and cell migration, PCD enables the organism to strictly control cell numbers and tissue size and to protect itself from unwanted cells that threaten cellular homeostasis [63]. Liu et al. [64] found that cell death progressed in a well-regulated manner in rice roots during salinity stress. This suggested a possible function of the dead cells in preventing the influx of excess $\mathrm{Na}^{+}$ions into the inner parts of roots and into shoots, leading to salt exclusion. It could also be possible that the plant sacrificed cells to prevent uncontrolled death and the release of toxins to protect and keep other cells growing. PCD is also reported to occur in the root tip of rice as a response to salinity stress [65].

\section{Approaches to Improve Salinity Stress Tolerance in Rice-Progress and Challenges}

To minimize the effect of salinity stress on rice, a number of strategies have been employed. Among these, water and soil management practices have facilitated agricultural production on soils marginalized by salinity but achieving additional gain by these approaches seems problematic. More recently, crop improvement strategies that are based on the use of molecular marker techniques and biotechnology are being used in conjunction with traditional breeding efforts to develop salt tolerant crop species $[50,60,61]$. Based on the known mechanisms that rice has to cope with salinity stress, the three major approaches of conventional breeding, marker assisted selection and genetic engineering have been used to enhance salt tolerance in rice. Progress to date shows some success but many challenges. 


\subsection{Conventional Breeding}

Conventional breeding has been used for production of salt tolerant rice varieties through two basic steps [66]. The first is to generate/obtain a breeding population that is highly variable for salt tolerance; and the second involves selection among the segregating progeny for individuals that combine most of the parent's useful traits and high degree of salt tolerance. There are two important factors for determining salinity tolerance, threshold and slope. Threshold indicates the highest permissible salt level without reduction in yield. Slope indicates per cent reduction in yield per unit rise in salt level above the threshold. The threshold of rice is $3.0 \mathrm{dSm}^{-1}$ and slope is $12 \%$ per $\mathrm{dSm}^{-1}$ [67]. Rice plants respond differently to salinity depending on the stage of development, type and concentration of salt, duration of exposure, water regime, soil $\mathrm{pH}$, humidity, solar radiation and temperature [68].

By using several methods such as introduction, hybridization and mutagenesis for generation of highly variable salt tolerant breeding populations, considerable success has been obtained in raising rice genotypes with improved tolerance towards salinity [69-76]. Attempts to improve salt tolerance in rice by conventional breeding, however, have experienced difficulties. One of the reasons is that it is difficult to establish the physiological characters which best define salt tolerant genotypes. These traits are controlled by numerous genes that generate a continuous variation, the so-called "quantitative trait loci" (QTL) [77]. In addition, limited parental resources for breeding also contributes to limited success of breeding programs for enhanced rice salinity stress tolerance.

The idea of using physiological criteria for screening salt tolerance has been embraced by many researchers [78-82]. Basically, it could be possible to increase resistance to salinity beyond the existing phenotypic range by selecting individual physiological traits that contribute to salt resistance and combining them in a breeding programme $[69,70]$. However, no salt tolerant varieties have been developed and released by using this approach to date. Thus, the use of yield loss under stress to measure salt tolerance in the controlled environment has been considered more reliable and efficient method than using the physiological traits or conducting trails in field conditions [83].

Another complication that needs to be considered when breeding for salinity tolerance in rice is that different rice varieties have varied levels of salinity tolerance at different growth stages. Rice is comparatively tolerant to salinity stress during germination, active tillering, and towards maturity, but is sensitive during early seedling and reproductive stages. Moreover, salinity tolerance at the seedling and reproductive stages are only weakly, if at all, associated [84]. It has been reported that salinity tolerance at the seedling stage is independent of salinity tolerance at flowering/reproductive stage [85], for example, CN499-160-13-6 genotype has been confirmed as susceptible at seedling stage, but tolerant at the flowering stage [86]. Due to the variation in sensitivity to salinity during the life cycle, evaluation of salinity tolerance in rice is complex [87]. Some varieties have been found to be comparatively tolerant at the flowering stage due to better viability of pollen and higher grain yield (up to $40 \%$ ) under salinity stress. This occurred in varieties such as Karalata, Pokkali, IR72046-B-R-7-3-1-2, etc., but other genotypes such as IR66946-3R-178-1-1 and IR65858-4B-11-1-2 have been categorized as sensitive at the flowering stage due to reduced grain yield, although high pollen viability occurred [88]. Therefore, screening of salinity tolerance in breeding programs has been suggested in two steps: (i) screening seedling salinity tolerance for large segregating populations (early generation screening) under controlled conditions; and (ii) testing salinity tolerance of promising lines from the first round screening at the reproductive stage, preferably under the field conditions [83].

Despite some variation in the gene pool for salinity tolerance in rice, those with good salinity tolerance have poor agronomic characteristics, and thus are not potential salinity tolerant donors in breeding programs for improvement of salinity tolerance. Comparison of the relative tolerance (measured as the survival of seedlings in a salinized hydroponic system) of seven wild species of rice and the two cultivated species, O. sativa and O. glaberrima, found that none of the wild species were as tolerant as the most tolerant of the cultivated lines of O. sativa tested, such as Nona Bokra [89]. Of the remaining ten or so species within genus Oryza, there is no information concerning their tolerance to 
salinity, except for Porteresia coarctata Takeoka which is a native of salt-marshes around the coasts of the Bay of Bengal, and can grow in as high as $20 \%$ seawater without any adverse effect on growth [90]. Between the two main subspecies of rice, it is observed that Indica is more tolerant than Japonica. Tolerant Indica varieties are good $\mathrm{Na}^{+}$excluders, absorb high amounts of $\mathrm{K}^{+}$, and maintain a low $\mathrm{Na}^{+} / \mathrm{K}^{+}$ratio in the shoot [46]. This also demonstrates that there is a great variation in salinity tolerance among rice varieties [91-94].

Although many successes in breeding salinity tolerant rice varieties have been reported, the fact is that the use of traditional salt tolerant parents such as Nona Bokra, Pokkali SR26B, and Kalarata do not possess the level of tolerance found [67]. Most salt tolerant rice landraces and cultivars have poor agronomic characteristics such as tall plant stature, poor grain quality, low yield, and photosensitivity $[67,68]$. Pokkali has been recognized for providing more salt tolerance when compared to other tolerant cultivars and thus it is used as a highly potential salt tolerant donor [87]. In this cultivar, a major QTL (Saltol) was identified which is located on chromosome 1 and involved in salt tolerance at the vegetative stage [95]. This QTL caused $64-80 \%$ of the phenotypic variation under saline conditions which has also been confirmed in other varieties of rice such as Nona Bokra $[85,88,96]$. Another rice variety FL478 (IR 66946-3R-178-1-1, derived from crossing between Pokkali and IR 29), has been promoted as an improved donor for breeding programs, as it has a high level of seedling stage salinity tolerance and is photoperiod insensitive, shorter and flowers earlier than the original Pokkali. FL478 also maintains a lower $\mathrm{Na}^{+} / \mathrm{K}^{+}$ratio than both the parent lines [97,98]. Based on its ability to tiller well and maintain high potassium content under salinity stress, FL478 appears to be a good candidate for salinity stress tolerance in rice, particularly at the vegetative stage of growth.

\subsection{Marker Assisted Selection}

Recently, success in improving salt tolerance in rice relied on a remarkable effort to identify a major quantitative trait locus (QTL) contributing to salt tolerance in rice. A major QTL designed "Saltol" was mapped on chromosome 1 using a population generated from a cross between the sensitive variety IR29 and a tolerant landrace, Pokkali. This QTL accounts for more than 70\% of the variation in salt uptake in this population and marker assisted backcrossing is being used to incorporate this QTL into popular varieties sensitive to salt stress [84].

Salt tolerance is a complex trait, so the QTLs related with salt tolerance have a significant role in understanding the stress-response and generating stress-tolerant plants [86]. As mentioned above, remarkable efforts have been made in identifying QTLs and their components affecting salt tolerance. There are many methods for identifying gene/QTLs such as traditional map-based cloning [99], new approaches like microarray based transcriptional profiling of differential gene expression [100] or combination of genetic mapping and expression profiling [101,102]. Several QTLs involved in salt tolerance have been reported. For example twenty-five major QTLs, each explaining more than $10 \%$ of the phenotypic variance, were mapped on chromosomes 1, 2, 3 and 8 from a mapping population F2 between salt tolerance variety CSR27 and MI48, using 79 SSR and EST markers distributed over the twelve rice chromosomes at an average interval of $20.7 \mathrm{cM}$ and total map distance of $1634.5 \mathrm{cM}$. These included one QTL for seedling salt injury score, nine for $\mathrm{Na}^{+}$concentration, three for $\mathrm{K}^{+}$concentration and four for $\mathrm{Cl}^{-}$concentration in leaf and stem tissues at vegetative and reproductive stages [103]. Using the same population, a combination of genetic mapping and bulked transcriptome profiling was used to narrow down the number of differentially expressed salt-responsive genes. Eight significant QTL intervals were mapped on chromosomes 1, 8, and 12 for the salt ion concentrations and a QTL controlling stress susceptibility index (SSI) for spikelet fertility was co-located in one of these intervals on chromosome 8. However, a total 2681 genes in these QTL intervals, made it difficult to pinpoint the genes responsible for the functional differences for the traits [102]. Another study analyzing 100 SSR markers on 140 IR29/Pokkali recombinant inbred lines (RILs) confirmed the location of the Saltol QTL on chromosome 1 and identified additional QTLs associated with tolerance. Analysis of a series of backcross lines and near-isogenic lines [104] 
developed to better characterize the effect of the Saltol locus revealed that Saltol mainly acted to control shoot $\mathrm{Na}^{+} / \mathrm{K}^{+}$homeostasis $[105,106]$.

With a better understanding of the mechanisms and genetics of salt tolerance, more precise breeding approaches have been used for developing higher salt tolerance. Marker assisted selection (MAS) has been seen as a means of improving the speed and efficiency of breeding programs because it is growth stage independent, is unaffected by environment, has no dominance effect and is efficient to use in early generations. Marker assisted backcrossing (MABC) is another useful method for introgression or substitution of a target gene/QTL from salt tolerant parent to recipient by applying molecular markers. There are several successful examples where Saltol QTL has been precisely introgressed into elite rice varieties through MABC such as PB1121 and PB6 [107], AS996 [108], Bac Thom 7 [109,110] and BRRI Dhan-49 [111].

The drawbacks in using marker assisted selection are, besides a relatively high cost, "linkage drag" of undesirable traits due to the large size of regions of chromosome identified by QTL [112] and the fact that environment and genetic background have a significant influence on the QTL that are identified [113]. Thus, challenges still remain for further improvement to make MAS and MABC more affordable and reliable tools for breeding salt tolerance in rice.

\subsection{Genetic Engineering}

Genetic modification has become a powerful tool in plant breeding programs since it allows the introduction of gene(s) controlling traits without affecting the desirable characteristics of an elite genotype [56]. The advent of an efficient Agrobacterium-mediated transformation method for rice [114] displays great potential from the genetic improvement of this plant. To date, genetic engineering for salinity tolerance in plants has focused on genes that encode compatible organic solutes, antioxidants (detoxification of ROS), ion transport, heat-shock and late embryogenesis abundant proteins, programmed cell death, signal transduction and transcription factor (Table 1). Generally, all of the known mechanisms that rice uses to cope with salinity have been brought into genetic engineering programs to generate salinity tolerance in rice.

Table 1. Summary of genetic engineering approach for salinity stress tolerance in rice.

\begin{tabular}{|c|c|c|c|c|c|}
\hline Gene & Protein & Gene Sources & DS & Comments & Reference \\
\hline \multicolumn{6}{|c|}{ Machinery: Antioxidants and ROS detoxification } \\
\hline CAT1 and GST & $\begin{array}{l}\text { Catalase and } \\
\text { Glutathione } \\
\text { S-transferase }\end{array}$ & Suaeda salsa & $\mathrm{G}, \mathrm{V}$ & $\begin{array}{l}\text { Enhanced salt tolerance. Increased GST, } \\
\text { CAT and SOD activities; Decreased } \mathrm{H}_{2} \mathrm{O}_{2} \\
\text { and Electrolytes leakage. }\end{array}$ & [115] \\
\hline GlyII & Glyoxalase II & Oryza sativa & $\mathbf{V}$ & $\begin{array}{l}\text { Enhanced salt tolerance. Increase } \\
\text { Glyoxalase }(1,2,3 \text { and } 4) \text { activities. } \\
\text { Increased shoot/root dry weight; } \\
\text { accumulate less } \mathrm{Na}^{+} \text {, more } \mathrm{K}^{+} \text {. }\end{array}$ & [116] \\
\hline GS2 & $\begin{array}{l}\text { Chloroplastic } \\
\text { Glutamine } \\
\text { synthetase }\end{array}$ & Oryza sativa & $\mathrm{V}$ & $\begin{array}{l}\text { Enhanced salt tolerance. Higher quantum } \\
\text { yield of PSII, less } \mathrm{Na}^{+} \text {accumulation. }\end{array}$ & [117] \\
\hline katE & Catalase & Escherichia coli & $\mathrm{V}$ & $\begin{array}{l}\text { Enhanced salt tolerance. Increase catalase } \\
\text { activities. Less damage by } \mathrm{NaCl} \text { at both } \\
\text { developmental stages. }\end{array}$ & {$[118,119]$} \\
\hline$M n-S O D$ & $\begin{array}{l}\text { Mitochondrial } \\
\text { manganese } \\
\text { superoxide } \\
\text { dismutase }\end{array}$ & $\begin{array}{l}\text { Saccharomyces } \\
\text { cerevisiae }\end{array}$ & $\mathrm{V}$ & $\begin{array}{l}\text { Enhanced salt tolerance. Increase SOD } \\
\text { activities. Higher quantum yield of PSII. }\end{array}$ & [120] \\
\hline Sod1 dismutase & $\begin{array}{l}\text { Cytosolic copper } \\
\text { zinc superoxide }\end{array}$ & $\begin{array}{l}\text { Avicennia } \\
\text { marina }\end{array}$ & $\mathrm{V}$ & $\begin{array}{l}\text { Enhanced salt tolerance. Higher fresh } \\
\text { weight and dry weight in transgenic plants } \\
\text { than non-transgenics. }\end{array}$ & [121] \\
\hline
\end{tabular}


Table 1. Cont.

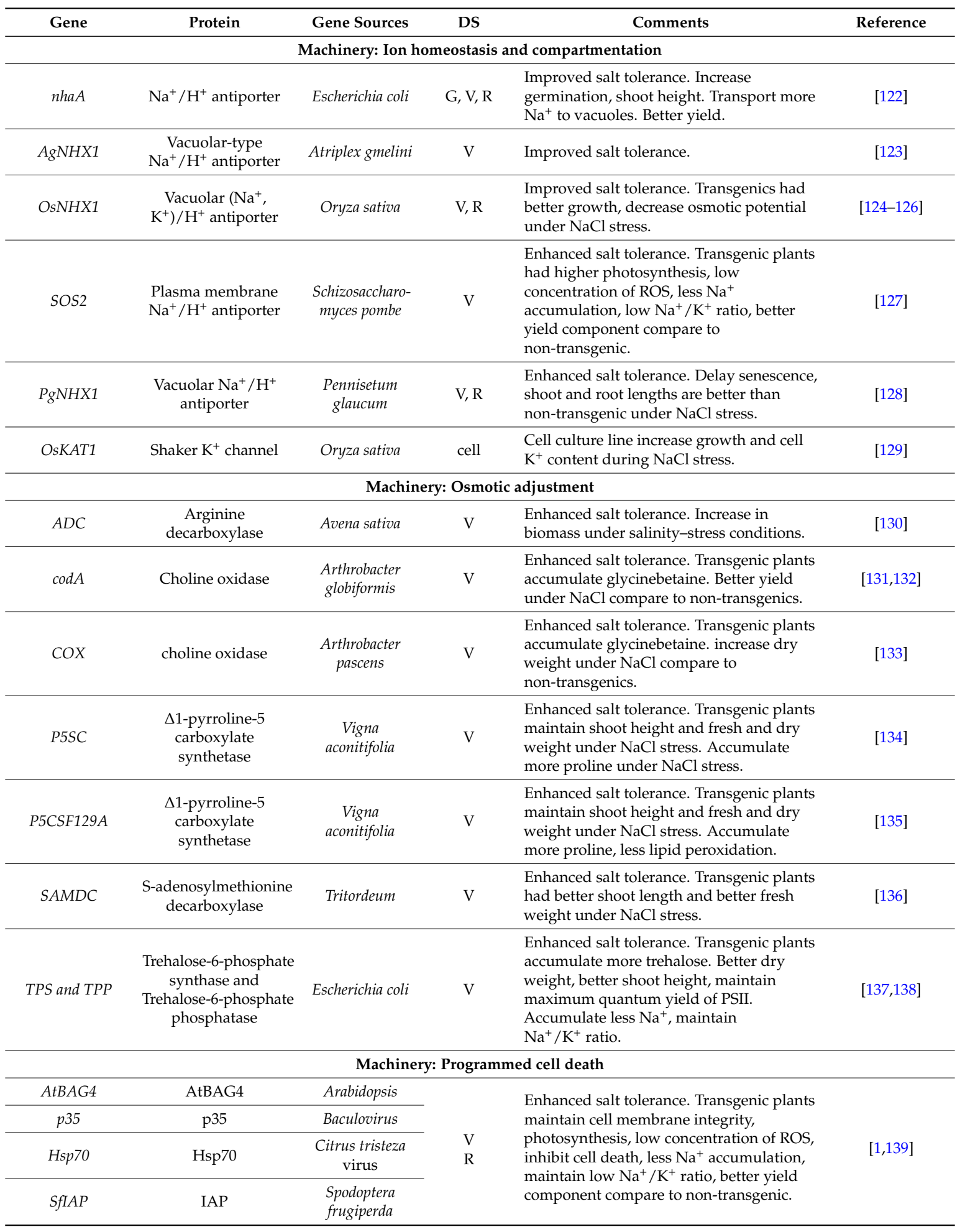


Table 1. Cont.

\begin{tabular}{|c|c|c|c|c|c|}
\hline Gene & Protein & Gene Sources & DS & Comments & Reference \\
\hline \multicolumn{6}{|c|}{ Machinery: Signal transduction } \\
\hline HVA1 & LEA & $\begin{array}{l}\text { Hordeum } \\
\text { vulgare }\end{array}$ & $\mathrm{V}$ & $\begin{array}{l}\text { Enhanced salt tolerance. Transgenic plants } \\
\text { maintain better growth, plant height, root } \\
\text { fresh weight under } \mathrm{NaCl} \text { stress. }\end{array}$ & {$[140,141]$} \\
\hline OsCDPK7 & CDPK & Oryza sativa & $\mathrm{V}$ & $\begin{array}{l}\text { Enhanced salt tolerance. Transgenic plants } \\
\text { survived better under } \mathrm{NaCl} \text { stress. }\end{array}$ & [142] \\
\hline OsMAPK5 & MAPK & Oryza sativa & $\mathrm{V}$ & Enhanced salt tolerance & [143] \\
\hline CNAtr & Calcineurin & Mouse & $\mathrm{V}$ & $\begin{array}{l}\text { Enhanced salt tolerance. Less } \mathrm{Na}^{+} \\
\text {accumulated in roots. Root growth was less } \\
\text { inhibited than shoot growth under } \\
\mathrm{NaCl} \text { stress. }\end{array}$ & [144] \\
\hline \multicolumn{6}{|c|}{ Machinery: Transcription factor } \\
\hline $\begin{array}{l}\text { OPBP1 } \\
\mathrm{AP} 2 / \mathrm{ERF}\end{array}$ & transcription factor & Tobacco & $\mathrm{V}$ & $\begin{array}{l}\text { Enhanced salt tolerance. Transgenic plants } \\
\text { survived salt shock while non-transgenic } \\
\text { die off. }\end{array}$ & [145] \\
\hline $\begin{array}{l}C B F 3 / D R E B I A \\
(C B F 3) \\
\text { and } A B F 3\end{array}$ & transcription factor & Arabidopsis & $\mathrm{V}$ & $\begin{array}{l}\text { Enhanced salt tolerance. Transgenic } \\
\text { improved growth and maximum quantum } \\
\text { yield of PSII. }\end{array}$ & [146] \\
\hline
\end{tabular}

Despite some promising reports, the development of a salt-tolerant cultivar by way of transgenics still awaits more investigation. To date, no genetic engineered rice for enhanced salinity tolerance has been commercialized. Despite all the genes that have been introgressed into rice improve salinity tolerance (Table 1), a transgenic salt tolerant variety still has not reached the farmer. There are two major challenges that may hinder the success of this approach.

Firstly, there are a number of genes involved in salinity tolerance in rice but the gene that determines the major response to salinity stress has not yet been confirmed. Currently, the genetic engineering approach for salinity stress tolerance in rice has mostly transformed single genes in one of the four categories of salt stress response into rice (i.e., osmoprotectant, antioxidants, ion transporter or programmed cell death). Existing evidence suggests that members of protein families involved in ion transport, osmoregulation, and protection from oxidative damage are essential in governing high salt tolerance [100]. The response to salinity stress of Pokkali, the natural salt tolerant rice variety, showed that this variety may employ several strategies to cope with salt stress such as transient uptake $\mathrm{Na}^{+}$into cytoplasm and fast extrusion $\mathrm{Na}^{+}$into vacuoles [48] and increase activities of ROS scavenging enzyme such as catalase (CAT) and enhanced levels of antioxidants like ascorbate (ASC) and glutathione (GSH) during salt stress [51]. No dominant salt tolerance strategy has been determined for this variety. In addition, there was a weak link between tolerance to salinity stress at seedling and reproductive stages in some genotypes within the species Oryza saltiva L., which also makes it difficult to ensure that a single transgene can strongly enhance salt tolerance in transgenic rice for the whole life cycle. Therefore, it would be worth trying to introgress a locus consisting of genes from different salt response categories into rice for enhanced salt tolerant in this important crop.

Another reason that may contribute to the limited outcome of the genetic engineering approach for enhanced salinity stress tolerance in rice is gene silencing. Despite significant scientific and technical advances in gene expression systems and plant transformation technologies, many transgenic plants do not display the expected transgene expression. Furthermore, numerous reports demonstrated considerable differences in transgene expression between transgenic lines harbouring the same cassette as well as within the same line over multiple generations. Whilst many of these differences were most probably due to influences of the adjacent host chromosome sequences, it is increasingly obvious that factors other than the integration site and strength of the transgene promoter were also involved [147]. It is now known that epigenetic effects and gene silencing have large influences on gene expression either by transcriptional gene silencing (TGS) or post-transcriptional gene silencing (PTGS). Unfortunately, gene silencing is notoriously unpredictable and represents a significant bottleneck to 
the success of transgenic systems. Gene silencing can be triggered by the presence of foreign genes or additional copies of endogenous genes; interestingly, it has also been observed against endogenous genes in non-transgenic plants [148,149].

Silencing may occur at the transcriptional or post-transcriptional level. Transcriptional gene silencing is an irreversible process that occurs when dsRNA molecules target promoter regions resulting in methylation and termination of transcription $[150,151]$. Post-transcriptional silencing on the other hand occurs when dsRNA molecules derived from transcribed regions are processed by silencing machinery and the subsequent short RNAs target and degrade homologous transcript sequences. Unlike TGS however, PTGS is often reversible and used as a quick acting regulator of transcript half-life and subsequent gene expression [152]. The molecular processes of both TGS and PTGS have both been well characterized and are not in the scope of this review, and for further information please see the review by Rajeekumar et al. [153]. Numerous studies have also reported transgene silencing in rice [154-156]. To obtain the desired results from transgenic technologies, it is imperative to mitigate the levels of transgene silencing and control gene expression at anticipated levels.

To overcome transgene silencing, researchers have developed a range of strategies including extrachromosomal episomal expression, artificial chromosomes, incorporation of introns into transgene coding regions and expression of viral silencing suppressors. Over the last three decades, significant progress has been made towards the mechanisms underpinning gene silencing and the advent of transgenics has significantly accelerated this progress. With this understanding is an increased knowledge of the factors surrounding transgene expression stability. The emerging technologies of genome editing allow scientists to control the transformation process to either be integration free or at least direct the integration location. This control will no doubt lead to further discoveries and possibly lead to new platforms that alleviate transgene silencing to increase the stability of transgene expression.

\section{Opportunity}

We have already highlighted the challenges that hinder the improvement of salinity stress tolerance in rice including: (i) limited parental resources for conventional breeding; and (ii) the complexity of salinity tolerance leading to modest success in both marker assisted selection and genetic engineered approaches for enhanced salinity tolerance in rice. Here, we will discuss: (i) the potential of using wild rice as resources for desalinization in irrigated land as well as genetic resources for both conventional breeding and genetic engineering; and (ii) potential of using genome editing to improve salinity tolerance in rice (Table 2).

\subsection{Wild Rice-A Potential Candidate for Desalinization Crop}

Irrigation leads to salinization. Each year approximately two million ha of irrigated land becomes uncultivable due to excessive salts [4]. A common method used to reclaim salt-affected soils is leaching, a process in which an excess amount of water is applied to dissolve and remove salts in soils, particularly from root zones by passaging the water through soil profiles [157]. The standing water in a rice paddy can leach the salts in the soil surface to a reduced level, making the salt-affected soils more suitable for subsequent crops. Rice is probably the only crop that can grow well in flooded conditions. Therefore rice is recommended as a desalinization crop for reclamation of salt-affected soils [158], if the soil salinity is sufficiently reduced.

O. rufipogon, the progenitor of cultivated rice O. sativa, harbours QTLs that determine salt tolerance [159]. Tian et al. [159] identified 15 putative quantitative trait loci (QTLs) associated with four traits including salt tolerance score (STS), relative root dry weight (RRW), relative shoot dry weight (RSW) and relative total dry weight RTW in 87 introgression lines (ILs), which were derived from a cross between an elite indica cultivar Teqing and an accession of common wild rice (O. rufipogon Griff.) in China. The authors found that STS was significantly positively correlated with all other three traits. O. rufipogon-derived alleles at 13 QTLs (86.7\%) could improve the salt tolerance in the Teqing background. 
Further, O. rufipogon also possesses high quality grain. In a study of Australian wild rice growing in the natural floodplain environment, Wurm et al. [160] found that the protein content of O. meridionalis and O. rufipogon was similar at $10 \%$ protein and higher than the $7 \%$ protein reported for a large number of pooled samples of $O$. sativa [160]. Concentrations of zinc, calcium, manganese and phosphorus were also higher in the grains of the wild rices than the pooled values for O. sativa. Cheng et al. [161] investigated the nutritional components of O. rufipogon, O. officinalis, and O. granulata and determined the protein content in the husked rice grains to be $14.5 \%, 16.3 \%$ and $15.3 \%$, respectively, significantly higher than for six O. sativa cultivars. One sample of $O$. officinalis had a protein content as high as $19.3 \%$. The same study found that the sulphur, phosphorus, magnesium, zinc, and ferrite content in the three wild rice species was $30 \%-158 \%$ higher than that of the six O. sativa cultivars. Variability in genetic traits responsible for the accumulation of micro- and macro-nutrients in wild rice is greater than in O. sativa [162].

\subsection{Wild Rice-An Invaluable Genetic Resource}

The International Rice Research Institute (IRRI) recognises 25 wild Oryza species, in addition to the two cultigens (O. sativa and O. glaberrima) (IRRI, n.d.). Wild relatives of Oryza, are a genetic resource underpinning the future of a major food crop, at a time when agricultural systems will be required to accommodate adaptation to climate change, while feeding an increasing population [163]. Wild Oryza species in the A-genome group are of most interest, as the A-genome group includes the two cultivated species, O. sativa and O. glaberrima. The wild A-genome species of African origin are perennial O. longistaminata and annual O. barthii, of South America origin is the perennial O. glumaepatula, of Austral-Asia origin are perennial O. rufipogon and annuals O. nivara and O. meridionalis [15].

Sequencing of the genomes of the following wild rice species has already been completed: O. brachyantha [164] O. barthii, O. glumaepatula, O. meridionalis, O. nivara [165], O. barthii, O. glumaepatula, O. longistaminata, O. meridionalis, O. nivara, O. punctata and O. rufipogon [166] in addition to African and Asian cultivated rice, O. glaberrima [165] and O. sativa. These studies reveal very high levels of genomic structural variation leading to considerable morphological and reproductive diversification [165]. Lineage-specific, protein-coding genes under positive selection included those involved in flower development, reproduction and biotic and abiotic defences. The O. meridionalis from northern Australia had great divergence in protein-coding genes, non-coding RNA genes, structural variation and specific functional enrichment of miRNA target genes. It was 2.5 -fold more distantly related to the other AA taxa than the genomes of the other species were to each other [165].

Unlike the densely populated rice growing areas in Asia where there is a tradition of rice cultivation spanning millennia, in northern Australia wild populations of A-genome O. meridionalis and O. rufipogon occur in vast swaths on the monsoonal floodplains of largely unmodified river catchments, and largely in the absence of cultigens. Recent work on these under-researched and possibly under-valued northern Australian populations of native Oryza have revealed new taxa [166-168]. These taxa were identified within perennial populations previously referred to as O. rufipogon. Waters et al. [167] focused on the chloroplast genome, using samples from just four individuals at a single site in each of Vietnam and northern Australia for O. rufipogon, and four individuals of O. meridionalis from a site in northern Australia. They found that the Australian O. rufipogon was more similar to the Australian O. meridionalis than it was to the Asian O. rufipogon. Following on from this work, a more extensive study was undertaken involving a larger number of accessions of O. rufipogon from in Asia and O. rufipogon and O. meridionalis from accessions and new field samples in Australia, about which morphological and ecological observations could be made in situ. Assessment of both nuclear and maternal genomes indicated that the taxon identified in Australia as O. rufipogon actually includes two types. One shares morphology and loci in the chloroplast genome with O. meridionalis. The other is more closely related to Asian O. rufipogon in the chloroplast genome, morphology and nuclear genome. This situation may be interpreted as indicating a common ancestor for Australian O. rufipogon and O. meridionalis and a later arrival of Asian O. rufipogon. Further work on this group of 
A-genome Oryza species, using whole chloroplast genomes found that these two perennial Australian taxa and O. meridionals were more similar to each other than to Asian O. rufipogon [166,168]. The genetic distance between Australian perennial Oryza Taxon A and both Asian O. sativa and O. rufipogon, was found to be similar to that between the Asian cultivated and wild species. This was interpreted as indicating that divergence of O. rufipogon in Asia and Oryza Taxon A in Australia was likely to have happened over a much longer period and been driven by allopatric evolution $[166,168]$. These authors point to opportunities for further investigations of nuclear genetic diversity for rice breeding resources.

During the processes of domestication and cultivation, useful genes for disease and pest resistance may introgress from wild relatives, and enable rice to adapt to new environments [15]. This has been recorded for bacterial blight (Xa21 from O. longistaminata, Xa23 from O. rufipogon and Xa27 from O. minuta) and blast disease (Pi9 from O. minuta) (see [169]). Ballini et al. [169] found that for O. sativa varieties IR64 and IR36 the blast resistance gene Pi33 introgressed from O. rufipogon, and that the large chromosome fragment associated with this introgression ( $25 \%$ of chromosome 8 ) indicates it has been preserved due to selection pressure.

However, introgression occurs in both directions. In most areas where wild rices grow, introgression from cultivated paddy fields nearby has occurred [15,165,170-172]. As a result, many accessions of wild rices are not necessarily representative of the wild genome $[15,165]$. Most populations of wild Oryza are under threat from habitat destruction and/or introgression from cultigens from paddy fields into nearby wild populations. For example in China, O. rufipogon is currently threatened due to habitat fragmentation and reduction, in addition to introgression from cultivated rice $[165,171,173]$. Rates of gene flow from cultivated rice to $O$. rufipogon have been measured as $1.1 \%$ to $2.2 \%$ [170] and up to $2.94 \%$ [173]. These high rates have led some to recommend actions such as the establishment of exclusion zones or pollen traps to be established between wild and cultivated populations to prevent ecological consequences, including if GM crops are being grown [170], in order to protect the biosafety of wild rice populations.

Gao [171] found that Chinese O. rufipogon demonstrated greater microsite variation within than among populations, and attributed this to pollen movement being restricted to less than 6-9 $\mathrm{km}$, or seed adapted to gravitational dispersal and immediate burial [174]. Pusadee et al. [172] found genetic distance among populations on the Indo-China Peninsula correlated with geographic distance, which specifically correlated with soil and temperature, possibly demonstrating the effects of environment on divergence.

Allele mining in wild rice populations for functionally understood genes may provide new resources for crop development. Porteresia coarctata (O. coartacta), occurring in coastal haline coastal wetlands has been identified as a model for understanding salinity tolerance in rice [175]. Investigation of diversity in OsDREB1F gene in O. nivara and O. rufipogon has found an association with drought tolerance. Some work has been undertaken to explore possible genetic and phenotypic adaptations of wild Australian rice to low soil P [176]. However, in that case, the environment from which the accessions were collected was not known, such that no link could be made back to adaptation to $P$ deficient soils. Collection of accessions could be targeted according to habitat gradients across the range of wild populations. Australian A-genome wild rice occurs in expansive floodplains across monsoonal northern Australia [177]. The processes that have led to the development of these floodplains began approximately 6000 years ago when sea level rise meant estuarine and then mangrove sediments were deposited in the river valley floors [178,179]. By 4000 years ago, mangrove substrates began to be overlain by freshwater deposition and then these have been reasonably stable at their present level for some 1500 years [178] and current floodwater sediment loads are low [180]. In some places, the saline estuarine sediments are less than $1 \mathrm{~m}$ below the flood plain soil $[178,179]$, and fossil shells of mangrove gastropods make their way to the floodplain surface far from extant mangroves (Penelope Wurm personal observation). The floodplain landform includes expansive gentle slopes, back swamps along the landward edge and below sea level in places, relict ox-bow lakes, and tidal creeks and, more recently, expanses of salt water intrusion. Soils are predominantly heavy grey cracking clay 
vertisols that are chemically highly variable [181]. Soil $\mathrm{pH}$ ranges from acidic to alkaline, and salinity to some degree is common $[181,182]$. Soil fertility appears to be very variable with extractable $\mathrm{P}$ ranging from 5 to $34 \mathrm{ppm}$ an extractable $\mathrm{K}$ from 40 to $1015 \mathrm{ppm}$ and total $\mathrm{N}$ from $0.14 \%$ to $0.86 \%$ [181]. How this habitat variability is reflected in the allele diversity of A-genome Australian wild rice is yet to be investigated.

In the face of the threats of both habitat destruction and introgression from cultigens, the wild rice populations of northern Australia comprise a globally significant, intact biodiversity resource. The extensive Australian populations of O. meridionalis, O. rufipogon and O. australiensis (E-genome) have been largely isolated from cultigens. However, cultivation of rice in tropical Australia is expanding. Cultivated rice has been trialled in the Northern Territory on the Adelaide River floodplain at Fogg Dam between 1950s and 1970s [183] and then currently at Tortilla Flats (Northern Territory Government, n.d.), in Western Australia in the Ord River region in the 1970s and 1980s and then currently since 2009 (Western Australian Government, n.d.), and in Queensland at Proserpine, Burdekin and Mackay [184]. Rice is also grown in temperate Australia in the Murray-Darling River Basin. However, unlike temperate growing areas, many of the rice sites where rice is being trialled (or may have escaped) in tropical northern Australia are likely to be adjacent to wild populations. Given the as yet unexplored significance of Australian native rice to global food production, their conservation and management should be considered in equal weight to the cultivation of $O$. sativa in northern Australia.

\subsection{The Next Frontier-The Use of Genome Editing for Integration Free Improvement of Crop Traits}

The advent of plant transformation technologies allowing the regeneration of transgenic plants from singularly transformed cells in the 1980s introduced a powerful tool to plant molecular biologists and enabled the discovery of fundamental concepts of plant biology [185]. Since these initial discoveries, significant progress has been made in the field of transgenics including improved control over integration, targeted modification to DNA sequences and marker free transformation systems. Recently, more sophisticated approaches that enable integration free "editing" of specific host DNA sequences have been developed. These next generation strategies are based on the formation of specific double stranded DNA breaks (DSBs) at desired genome targets and the use of host DNA repair systems to generate the desired changes using non-homologous end joining (NHEJ) or less commonly homologous recombination (HR). A critical breakthrough enabling the development of genome editing was the identification of sequence specific nucleases (SSNs) that efficiently make specific DSBs in complex genomes.

\subsubsection{Genome Editing Technologies}

Currently, several approaches are available for the creation of sequence specific DSBs that are used for genome editing. Meganucleases, TAL effector nucleases (TALENs) and zinc finger nucleases (ZFNs) all use synthetic DNA-binding proteins that recognize specific DNA targets. Although effective, these systems required significant modification depending on the desired target. The recent advent of the clustered regularly interspersed short palindromic repeats (CRISPR)/Cas system has dramatically improved the simplicity of genome editing and made it accessible to researchers worldwide. The CRISPR/Cas systems take advantage of prokaryote defence systems designed to remove foreign DNA. Essentially, the foreign DNA is flanked by host repeat sequences and transcribed as a CRISPR RNA. This CRISPR RNA directs a sequence specific nuclease Cas9 to create double stranded nicks in the genome [186]. The use of the guide RNA in the CRISPR/Cas9 system separates it from the three other methods which require extensive protein engineering. In CRISPR/Cas9 only the $20 \mathrm{bp}$ guide sequence is required to be modified thus providing added flexibility of the target sequence. Other advantages of the CRIPR/Cas system include: (i) increased number of potential recombination sites compared to ZFNs; (ii) improved delivery due to the small size of the guide RNAs compared to TALEN and ZFN vector systems; (iii) target specificity of CRISPR/Cas enables multiplexing potential. Accordingly, CRISPR/Cas has been the technology of choice in recent years and has been utilized 
for the editing of a range of plants including, Arabdiopsis, tobacco, wheat, rice, corn and sorghum. As a global staple with a relatively small genome size with efficient transformation systems already established. Rice is an ideal target for use within genome editing strategies.

Recent studies have shown improved resistance to rice blast by mutating the OsERF922 gene using the CRISPR/Cas system [187]. Genome edited plants containing the mutant OsERF922 gene but not DNA integration were selected in the $\mathrm{T} 1$ population following segregation and demonstrated a significant reduction in the number of lesions upon challenge with rice blast [187]. In other studies by $\mathrm{Xu}$ et al. [188], it was shown that CRISPR/Cas derived mutations are inheritable and integration-free in genome-modified rice in as early as the T1 generation. It is becoming apparent that genome modification of rice will be a powerful tool for the improvement of rice in future applications.

It is often desired to incorporate specific mutations in the host genome sequence without additional integrations. In contrast to transgenic approaches, genome editing does not involve transgene integration but rather incorporation of DNA modifications which are directed by homology-dependent repair. Despite the advantages of the CRISPR/Cas9 and other genome modification strategies, many are still hindered by the presence of integrated sequences that must be removed by segregation in future generations. Thus, to realize the full potential of genome modification strategies for the improvement of rice research, this issue needs to be addressed. Recent studies therefore have focused on eliminating DNA integration in combination with genome editing.

\subsubsection{Strategies to Minimize Transgene Integration}

Studies have shown that Agrobacterium strains containing dysfunctional VirD2 protein display significantly reduced T-DNA integration. Importantly, transient expression directed by the mutant Agrobacterium was only mildly affected and thus these strains demonstrate potential utilization in genome editing applications. Alternatively, research has been performed on the chemical modification of the DNA coating of gold particles used for microprojectile bombardment that prevents DNA introduction into the nucleus, thus allowing transient expression but not stable integration. The bombardment of single stranded DNA that cannot be integrated is another potential strategy to avoid template integration for genome editing approaches. Although these technologies are not fully developed, these encouraging results suggest that efficient genome editing systems within DNA integration will be developed and utilized for the improvement of rice. Finally, although the jury is still out on whether genome edited crops will undergo the same regulatory requirements as their transgenic siblings, at the very least, the power that genome editing provides for research scientists to target DNA regions provides exceptional power for the characterization of specific plant genes and improved rice varieties.

Table 2. Summary of challenges and opportunities for improvement of rice salinity stress tolerance.

\begin{tabular}{lll}
\hline \multicolumn{3}{c}{ Challenges } \\
\hline $\begin{array}{l}\text { Increased global salinisation } \\
\text { Ropid increase of the } \\
\text { world's population }\end{array}$ & $\begin{array}{l}\text { Limited parental resources for } \\
\text { conventional breeding }\end{array}$ & $\begin{array}{c}\text { Complexity of salinity tolerance in rice. } \\
\text { Many genes involve in salinity } \\
\text { stress tolerance in rice. } \\
\text { Transgene silencing }\end{array}$ \\
\hline $\begin{array}{l}\text { Wild rice-an excellent candidate } \\
\text { for desalinization crop }\end{array}$ & $\begin{array}{l}\text { Opportunities } \\
\text { Wild rice-an invaluable genetic } \\
\text { and other approaches }\end{array}$ & $\begin{array}{l}\text { The next frontier-the use of genome } \\
\text { editing for integration free } \\
\text { improvement of crop traits }\end{array}$ \\
\hline
\end{tabular}

\section{Conclusions}

Rice is the staple food for more than one half of the world's population and is grown widely in 114 countries across the world. Hence, an improvement in rice production would have a significant impact on communities. Rice is also recommended as a desalinization crop due to its ability to grow 
well in flooded conditions and the standing water in rice paddy can leach the salts out of the topsoil to make salt-affected land suitable for the subsequent crops [158]. Although many challenges impede attempts to improve salinity stress tolerance in rice, there are also a number of opportunities. Wild rice is a potential option for both: (i) a genetic resource for novel genes and mechanisms for salt tolerance; and (ii) a candidate for growing in salt-affected flooding areas subject to good salinity tolerance and high quality grain. Advanced technologies such as genome editing provide an excellent tool for reducing gene silencing in the genetic engineering approach for enhanced salinity tolerance in rice. It would also be the next frontier for integration-free improvement of crop traits with salinity stress tolerance as a target.

Acknowledgments: The authors acknowledge the Queensland University of Technology for funding the study through the Capacity development grant awarded to Sagadevan Mundree and the QUT Vice Chancellors research fellowship awarded to Brett Williams.

Author Contributions: All named authors made a substantial contribution to designing the review structure, searching and reviewing the literature. Thi My Linh Hoang wrote Sections 1, 2, 3.3 and part of Section 4.1; Thach Ngoc Tran and Thuy Kieu Tien Nguyen wrote Sections 3.1 and 3.2; Penelope Wurm and Sean Bellairs wrote Section 4.2 and part of Section 4.1; Brett William wrote Section 4.3; Sagadevan Mundree wrote Section 5 and reviewed the final manuscript for logic and expression.

Conflicts of Interest: The authors declare no conflict of interest.

\section{References}

1. Hoang, T.M.L.; Williams, B.; Khanna, H.; Dale, J.; Mundree, S.G. Physiological basis of salt stress tolerance in rice expressing the antiapoptotic gene SfIAP. Funct. Plant Biol. 2014, 41, 1168-1177. [CrossRef]

2. Food and Agriculture Organization. Salt-Affected Soils and Their Management. 1988. Available online: http://www.fao.org/docrep/x5871e/x5871e00.htm (accessed on 20 August 2016).

3. Munns, R. Genes and salt tolerance: Bringing them together. New Phytol. 2005, 167, 645-663. [CrossRef] [PubMed]

4. Umali, D.L. Irrigation-Induced Salinity a Growing Problem for Development and the Environment; The Word Bank: Washington, DC, USA, 1993.

5. Shrivastava, P.; Kumar, R. Soil salinity: A serious environmental issue and plant growth promoting bacteria as one of the tools for its alleviation. Saudi J. Biol. Sci. 2015, 22, 123-131. [CrossRef] [PubMed]

6. Munns, R.; Tester, M. Mechanisms of salinity tolerance. Annu. Rev. Plant Biol. 2008, 59, 651-681. [CrossRef] [PubMed]

7. Food and Agriculture Organization. Declaration of the World Summit on Food Security. Rome, Italy, 16-18 November 2009. Available online: http:/ /www.Fao.Org/wsfs/world-summit/wsfs-challenges/en/ (accessed on 20 August 2016).

8. Food and Agriculture Organization. World Water Day 2012 Celebration. Un Conference Centre, Bangkok, 22 March 2012. Available online: http://www.Fao.Org/asiapacific/rap/home/meetings/list/detail/en/ ?Meetings_id=637\&year=2012 (accessed on 20 August 2016).

9. The United Nations Population Fund. Linking Population, Poverty and Development. Available online: http://www.unfpa.org/pds/trends.htm (accessed on 8 February 2016).

10. Tester, M.; Langridge, P. Breeding technologies to increase crop production in a changing world. Science 2010, 327, 818-822. [CrossRef] [PubMed]

11. Eckardt, N.A. The future of science: Food and water for life. Plant Cell 2009, 21, 368-372. [CrossRef] [PubMed]

12. Cominelli, E.; Conti, L.; Tonelli, C.; Galbiati, M. Challenges and perspectives to improve crop drought and salinity tolerance. New Biotechnol. 2013, 30, 355-361. [CrossRef] [PubMed]

13. Munns, R. Plant adaptations to salt and water stress: Differences and commonalities. In Advances in Botanical Research; Ismail, T., Ed.; Elseiver: Wyman Street, Waltham, MA, USA, 2011; Volume 57, pp. 1-32.

14. Linares, O.F. African rice (Oryza glaberrima): History and future potential. Proc. Natl. Acad. Sci. USA 2002, 99, 16360-16365. [CrossRef] [PubMed]

15. Vaughan, D.A.; Lu, B.-R.; Tomooka, N. The evolving story of rice evolution. Plant Sci. 2008, 174, 394-408. [CrossRef] 
16. Virmani, S.S.; llyas-Ahmed, M. Rice breeding for sustainable production. In Breeding Major Food Staples; Kang, M., Priyadarshan, P.M., Eds.; Wiley: Hoboken, NJ, USA, 2008.

17. Hossain, M.; Fischer, K.S. Rice research for food security and sustainable agricultural development in Asia: Achievements and future challenges. GeoJournal 1995, 35, 286-298. [CrossRef]

18. Khush, G. What it will take to feed 5.0 billion rice consumers in 2030. Plant Mol. Biol. 2005, 59, 1-6. [CrossRef] [PubMed]

19. United States Department of Agriculture. Bibliography on Salt Tolerance. Fibres, Grains and Special Crops; Brown, G.E., Jr., Ed.; Salinity Laboratory United States Department of Agriculture Research Service: Riverside, CA, USA. Available online: http:/ / www.Ars.Usda.Gov/services/docs.Htm?Docid=8908 (accessed on 20 August 2016).

20. Rengasamy, P. World salinization with emphasis on Australia. J. Exp. Bot. 2006, 57, 1017-1023. [CrossRef] [PubMed]

21. Dayton, L. Agribiotechnology: Blue-sky rice. Nature 2014, 514, S52-S54. [CrossRef] [PubMed]

22. Maas, E.V.; Nieman, R.H. Physiology of plant tolerance to salinity. In Crop Tolerance to Suboptimal Land Conditions; ASS, CSA, SSSA: Madison, WI, USA, 1978; Volume 32, pp. 277-299.

23. Heenan, D.P.; Lewin, L.G.; McCaffery, D.W. Salinity tolerance in rice varieties at different growth stages. Aust. J. Exp. Agric. 1988, 28, 343-349. [CrossRef]

24. Zeng, L.; Shannon, M.C.; Lesch, S.M. Timing of salinity stress affects rice growth and yield components. Agric. Water Manag. 2001, 48, 191-206. [CrossRef]

25. Yeo, A.; Flowers, T. Salinity resistance in rice (Oryza sativa L.) and a pyramiding approach to breeding varieties for saline soils. Aust. J. Plant Physiol. 1986, 13, 161-173. [CrossRef]

26. Yancey, P.H. Organic osmolytes as compatible, metabolic and counteracting cytoprotectants in high osmolarity and other stresses. J. Exp. Biol. 2005, 208, 2819-2830. [CrossRef] [PubMed]

27. James, R.A.; Rivelli, A.R.; Munns, R.; Caemmerer, S.V. Factors affecting $\mathrm{CO}_{2}$ assimilation, leaf injury and growth in salt-stressed durum wheat. Funct. Plant Biol. 2002, 29, 1393-1403. [CrossRef]

28. Kader, M.A.; Lindberg, S. Cytosolic calcium and ph signaling in plants under salinity stress. Plant Signal. Behav. 2010, 5, 233-238. [CrossRef] [PubMed]

29. Garcia, A.B.; Engler, J.; Iyer, S.; Gerats, T.; Van Montagu, M.; Caplan, A.B. Effects of osmoprotectants upon nacl stress in rice. Plant Physiol. 1997, 115, 159-169. [CrossRef] [PubMed]

30. Kumar, V.; Shriram, V.; Nikam, T.D.; Jawali, N.; Shitole, M.G. Sodium chloride-induced changes in mineral nutrients and proline accumulation in indica rice cultivars differing in salt tolerance. J. Plant Nutr. 2008, 31, 1999-2017. [CrossRef]

31. Thu Hoai, N.T.; Shim, I.S.; Kobayashi, K.; Kenji, U. Accumulation of some nitrogen compounds in response to salt stress and their relationships with salt tolerance in rice (Oryza sativa L.) seedlings. Plant Growth Regul. 2003, 41, 159-164. [CrossRef]

32. Delauney, A.J.; Verma, D.P.S. Proline biosynthesis and osmoregulation in plants. Plant J. 1993, 4, $215-223$. [CrossRef]

33. Rhodes, D.; Hanson, A.D. Quaternary ammonium and tertiary sulfonium compounds in higher plants. Annu. Rev. Plant Physiol. Plant Mol. Biol. 1993, 44, 357-384. [CrossRef]

34. Rathinasabapathi, B. Metabolic engineering for stress tolerance: Installing osmoprotectant synthesis pathways. Ann. Bot. 2000, 86, 709-716. [CrossRef]

35. Chen, T.H.H.; Murata, N. Enhancement of tolerance of abiotic stress by metabolic engineering of betaines and other compatible solutes. Curr. Opin. Plant Biol. 2002, 5, 250-257. [CrossRef]

36. Harinasut, P.; Tsutsui, K.; Takabe, T.; Nomura, M.; Takabe, T.; Kishitani, S. Exogenous glycinebetaine accumulation and increased salt-tolerance in rice seedlings. Bioscie. Biotechnol. Biochem. 1996, 60, 366-368. [CrossRef] [PubMed]

37. Blumwald, E. Sodium transport and salt tolerance in plants. Curr. Opin. Cell Biol. 2000, 12, $431-434$. [CrossRef]

38. Shabala, S.; Cuin, T.A. Potassium transport and plant salt tolerance. Physiol. Plant. 2008, 133, 651-669. [CrossRef] [PubMed]

39. Wang, M.; Zheng, Q.; Shen, Q.; Guo, S. The critical role of potassium in plant stress response. Int. J. Mol. Sci. 2013, 14, 7370-7390. [CrossRef] [PubMed] 
40. Moradi, F.; Ismail, A.M. Responses of photosynthesis, chlorophyll fluorescence and ros-scavenging systems to salt stress during seedling and reproductive stages in rice. Ann. Bot. 2007, 99, 1161-1173. [CrossRef] [PubMed]

41. Maathuis, F.J.M.; Amtmann, A. $\mathrm{K}^{+}$nutrition and $\mathrm{Na}^{+}$toxicity: The basis of cellular $\mathrm{K}^{+} / \mathrm{Na}^{+}$ratios. Ann. Bot. 1999, 84, 123-133. [CrossRef]

42. Cuin, T.A.; Miller, A.J.; Laurie, S.A.; Leigh, R.A. Potassium activities in cell compartments of salt-grown barley leaves. J. Exp. Bot. 2003, 54, 657-661. [CrossRef] [PubMed]

43. Rodrigues, C.R.F.; Silva, E.N.; Ferreira-Silva, S.L.; Voigt, E.L.; Viégas, R.A.; Silveira, J.A.G. High K ${ }^{+}$supply avoids $\mathrm{Na}^{+}$toxicity and improves photosynthesis by allowing favorable $\mathrm{K}^{+}: \mathrm{Na}^{+}$ratios through the inhibition of $\mathrm{Na}^{+}$uptake and transport to the shoots of jatropha curcas plants. J. Plant Nutr. Soil Sci. 2013, 176, 157-164. [CrossRef]

44. Wang, H.; Zhang, M.; Guo, R.; Shi, D.; Liu, B.; Lin, X.; Yang, C. Effects of salt stress on ion balance and nitrogen metabolism of old and young leaves in rice (Oryza sativa L.). BMC Plant Biol. 2012, 12, 194. [CrossRef] [PubMed]

45. Dionisio-Sese, M.L.; Tobita, S. Effects of salinity on sodium content and photosynthetic responses of rice seedlings differing in salt tolerance. J. Plant Physiol. 2000, 157, 54-58. [CrossRef]

46. Lee, K.-S.; Choi, W.-Y.; Ko, J.-C.; Kim, T.-S.; Gregorio, G.B. Salinity tolerance of japonica and indica rice (Oryza sativa L.) at the seedling stage. Planta 2003, 216, 1043-1046. [CrossRef] [PubMed]

47. Ghosh, N.; Adak, M.K.; Ghosh, P.D.; Gupta, S.; Sen Gupta, D.N.; Mandal, C. Differential responses of two rice varieties to salt stress. Plant Biotechnol. Rep. 2011, 5, 89-103. [CrossRef]

48. Kader, M.A.; Lindberg, S. Uptake of sodium in protoplasts of salt-sensitive and salt-tolerant cultivars of rice, Oryza sativa L. Determined by the fluorescent dye SBFI. J. Exp. Bot. 2005, 56, 3149-3158. [CrossRef] [PubMed]

49. Miller, G.; Shulaev, V.; Mittler, R. Reactive oxygen signaling and abiotic stress. Physiol. Plant. 2008, 133, 481-489. [CrossRef] [PubMed]

50. Miller, G.A.D.; Suzuki, N.; Ciftci-Yilmaz, S.; Mittler, R.O.N. Reactive oxygen species homeostasis and signalling during drought and salinity stresses. Plant Cell Environ. 2010, 33, 453-467. [CrossRef] [PubMed]

51. Vaidyanathan, H.; Sivakumar, P.; Chakrabarty, R.; Thomas, G. Scavenging of reactive oxygen species in nacl-stressed rice (Oryza sativa L.) - Differential response in salt-tolerant and sensitive varieties. Plant Sci. 2003, 165, 1411-1418. [CrossRef]

52. Borsani, O.; Zhu, J.; Verslues, P.E.; Sunkar, R.; Zhu, J.-K. Endogenous sirnas derived from a pair of natural cis-antisense transcripts regulate salt tolerance in arabidopsis. Cell 2005, 123, 1279-1291. [CrossRef] [PubMed]

53. Zhu, J.; Fu, X.; Koo, Y.D.; Zhu, J.K.; Jenney, F.E.J.; Adams, M.W.; Zhu, Y.; Shi, H.; Yun, D.J.; Hasegawa, P.M.; et al. An enhancer mutant of arabidopsis salt overly sensitive 3 mediates both ion homeostasis and the oxidative stress response. Mol. Cell. Biol. 2007, 27, 5214-5224. [CrossRef] [PubMed]

54. Chawla, S.; Jain, S.; Jain, V. Salinity induced oxidative stress and antioxidant system in salt-tolerant and salt-sensitive cultivars of rice (Oryza sativa L.). J. Plant Biochem. Biotechnol. 2013, 22, 27-34. [CrossRef]

55. Asada, K. The water-water cycle in chloroplasts: Scavenging of active oxygens and dissipation of excess photons. Annu. Rev. Plant Physiol. 1999, 50, 601-639. [CrossRef] [PubMed]

56. Bhatnagar-Mathur, P.; Vadez, V.; Sharma, K.K. Transgenic approaches for abiotic stress tolerance in plants: Retrospect and prospects. Plant Cell Rep. 2008, 27, 411-424. [CrossRef] [PubMed]

57. Ashraf, M. Biotechnological approach of improving plant salt tolerance using antioxidants as markers. Biotechnol. Adv. 2009, 27, 84-93. [CrossRef] [PubMed]

58. Dionisio-Sese, M.L.; Tobita, S. Antioxidant responses of rice seedlings to salinity stress. Plant Sci. 1998, 135, 1-9. [CrossRef]

59. Hara-Nishimura, I.; Inoue, K.; Nishimura, M. A unique vacuolar processing enzyme responsible for conversion of several proprotein precursors into the mature forms. FEBS Lett. 1991, 294, 89-93. [CrossRef]

60. Greenberg, J.T. Programmed cell death: A way of life for plants. Proc. Natl. Acad. Sci. USA 1996, 93, 12094-12097. [CrossRef] [PubMed]

61. Williams, B.; Dickman, M. Plant programmed cell death: Can't live with it; can't live without it. Mol. Plant Pathol. 2008, 9, 531-544. [CrossRef] [PubMed]

62. Fomicheva, A.S.; Tuzhikov, A.I.; Beloshistov, R.E.; Trusova, S.V.; Galiullina, R.A.; Mochalova, L.V.; Chichkova, N.V.; Vartapetian, A.B. Programmed cell death in plants. Biochemistry 2012, 77, 1452-1464. [CrossRef] [PubMed] 
63. Hengartner, M.O. The biochemistry of apoptosis. Nature 2000, 407, 770-776. [CrossRef] [PubMed]

64. Liu, S.-H.; Fu, B.-Y.; Xu, H.-X.; Zhu, L.-H.; Zhai, H.-Q.; Li, Z.-K. Cell death in response to osmotic and salt stresses in two rice (Oryza sativa L.) ecotypes. Plant Sci. 2007, 172, 897-902. [CrossRef]

65. Li, J.-Y.; Jiang, A.-L.; Zhang, W. Salt stress-induced programmed cell death in rice root tip cells. J. Integr. Plant Biol. 2007, 49, 481-486. [CrossRef]

66. Breseghello, F.; Coelho, A.S.G. Traditional and modern plant breeding methods with examples in rice (Oryza sativa L.). J. Agric. Food Chem. 2013, 61, 8277-8286. [CrossRef] [PubMed]

67. Reddy, A.M.; Francies, R.M.; Rasool, S.N.; Reddy, V.R.P. Breeding for tolerance stress triggered by salinity in rice. Int. J. Appl. Biol. Pharm. Technol. 2014, 5, 167-176.

68. Ismail, A.; Heuer, S.; Thomson, M.; Wissuwa, M. Genetic and genomic approaches to develop rice germplasm for problem soils. Plant Mol. Biol. 2007, 65, 547-570. [CrossRef] [PubMed]

69. Lee, I.S.; Kim, D.S.; Lee, S.J.; Song, H.S.; Lim, Y.P.; Lee, Y.I. Selection and characterizations of radiation-induced salinitytolerant lines in rice. Breed. Sci. 2003, 53, 313-318. [CrossRef]

70. Oo, K.S.; Lang, N.T. Developing salt tolerance by mutagenesis. Omonrice 2005, 13, $126-134$.

71. Mba, C.; Afza, R.; Jain, S.M.; Gregorio, G.B.; Zapata-Arias, F.J. Induced mutations for enhancing salinity tolerance in rice. In Advances in Molecular Breeding toward Drought and Salt Tolerant Crops; Jenks, M.A., Hasegawa, P.M., Jain, S.M., Eds.; Springer: Dordrecht, The Netherlands, 2007; pp. 413-454.

72. Zapata, F.J.; Aldemita, R.R. Induction of salt tolerance in high yielding rice varieties through mutagenesis and anther culture. In Current Options for Cereal Improvement; Maluszyns-Ki, M., Ed.; Kluwer Acad: Dordrecht, The Netherlands, 1986; pp. 193-202.

73. Miah, M.A.A.; Pathan, M.S.; Quayum, H.A. Production of salt tolerant rice breeding line via doubled haploid. Euphytica 1996, 91, 285-288. [CrossRef]

74. Sathish, P.; Gamborg, O.L.; Nabors, M.W. Establishment of stable nacl-resistant rice plant lines from anther culture: Distribution pattern of $\mathrm{K}^{+} / \mathrm{Na}^{+}$in callus and plant cells. Theor. Appl. Genet. 1997, 95, 1203-1209. [CrossRef]

75. Wang, Y.; Zhang, L.; Nafisah, A.; Zhu, L.; Xu, J.; Li, Z. Selection efficiencies for improving drought/salt tolerances and yield using introgression breeding in rice (Oryza sativa L.). Crop J. 2013, 1, 134-142. [CrossRef]

76. Yen, C.-C.; Lin, J.-H. Screening, inheritance and linkage marker analyses of salt tolerance in mutated scented japonica rice (Oryza sativa L.). Plant Prod. Sci. 2011, 14, 260-269. [CrossRef]

77. Fita, A.; Rodríguez-Burruezo, A.; Boscaiu, M.; Prohens, J.; Vicente, O. Breeding and domesticating crops adapted to drought and salinity: A new paradigm for increasing food production. Front. Plant Sci. 2015, 6, 978. [CrossRef] [PubMed]

78. Epstein, E.; Norlyn, J.D.; Rush, D.W.; Kingsbury, R.W.; Kelley, D.B.; Cunningham, G.A.; Wrona, A.F. Saline culture of crops: A genetic approach. Science 1980, 210, 399-404. [CrossRef] [PubMed]

79. Shannon, M.C. Principles and strategies in breeding for higher salt tolerance. Plant Soil 1985, 89, $227-241$. [CrossRef]

80. Tal, M. Genetics of salt tolerance in higher plants: Theoretical and practical considerations. Plant Soil 1985, 89, 199-226. [CrossRef]

81. Rajanaidu, N.; Zakri, A.H. Breeding for morpho-physiological traits in crop plants. In Plant Breeding and Genetic Engineering; Zakri, A.H., Ed.; SABRAO: Bangkok, Thailand, 1988; pp. 116-139.

82. Yeo, A.R. Physiological criteria in screening and breeding. In Soil Mineral Stresses: Approaches to Crop Improvement; Yeo, A.R., Flowers, T.J., Eds.; Springer: Berlin, Germany, 1994; pp. 37-57.

83. Li, Z.-K.; Xu, J.-L. Breeding for drought and salt tolerant rice (Oryza sativa L.): Progress and perspective. In Advances in Molecular Breeding toward Drought and Salt Tolerance Crops; Jenks, M.A., Hasegawa, P.M., Jain, S.M., Eds.; Springer: Dordrecht, The Netherlands, 2007; pp. 531-564.

84. Lafitte, H.R.; Ismail, A.M.; Bennett, J. Abiotic stress tolerance in rice for asia: Progress and future. In Proceedings of the 4th International Crop Science Congress, Brisbane, Australia, 26 September-1 October 2004.

85. Jena, K.K.; MacKill, D.J. Molecular markers and their use in marker-assisted selection in rice. Crop Sci. 2008, 48, 1266-1276. [CrossRef]

86. Gorantla, M.; Babu, P.R.; Reddy, V.B.L.; Feltus, F.A.; Paterson, A.H.; Reddy, A.R. Functional genomics of drought stress response in rice: Transcript mapping of annotated unigenes of an indica rice (Oryza sativa L. cv. Nagina 22). Curr. Sci. 2005, 89, 496-514. 
87. Waziri, A.; Kumar, P.; Purty, R.S. Saltol QTL and their role in salinity tolerance in rice. Austin J. Biotechnol. Bioeng. 2016, 3, 1067-1072.

88. Ren, Z.; Gao, J.; Li, L.; Cai, X.; Huang, W.; Chao, D.; Zhu, M.; Wang, Z.; Luan, S.; Lin, H. A rice quantitative trail locus for salt tolerance encodes a sodium transporter. Nat. Genet. 2005, 37, 1141-1146. [CrossRef] [PubMed]

89. Akbar, M.; Jena, K.K.; Seshu, D.V. Salt tolerance in wild rices. Int. Rice Res. Inst. Newsl. 1987, $12,15$.

90. Flowers, T.J.; Flowers, S.A.; Hajibagheri, M.A.; Yeo, A.R. Salt tolerance in the halophytic wild rice, Porteresia coarctata takeoka. New Phytol. 1990, 114, 675-684. [CrossRef]

91. Flowers, T.J.; Yeo, A.R. Variability in the resistance of sodium chloride salinity within rice (Oryza sativa L.) varieties. New Phytol. 1981, 88, 363-373. [CrossRef]

92. Quijano-Guerta, C.; Kirk, G.J.D. Tolerance of rice germplasm to salinity and other soil chemical stresses in tidal wetlands. Field Crops Res. 2002, 76, 111-121. [CrossRef]

93. De Leon, T.B.; Linscombe, S.; Gregorio, G.B.; Subudhi, P.K. Genetic variation in southern USA rice genotypes for seedling salinity tolerance. Front. Plant Sci. 2015, 6, 374. [CrossRef] [PubMed]

94. Sakina, A.; Ahmed, I.; Shahzad, A.; Iqbal, M.; Asif, M. Genetic variation for salinity tolerance in pakistani rice (Oryza sativa L.) germplasm. J. Agron. Crop Sci. 2016, 202, 25-36. [CrossRef]

95. Bonilla, P.S.; Dvorak, J.; MacKill, D.; Deal, K.; Gregorio, G.B. RFLP and SSLP mapping of salinity tolerance genes in chromosome 1 of rice (Oryza sativa L.) using recombinant inbred lines. Philipp. Agric. Sci. 2002, 85, 64-74.

96. Takeshisa, H.; Shimoda, Y.; Fukuta, Y.; Ueda, T.; Yano, M.; Yamaya, T.; Kameya, T.; Sato, T. Identification of quantitative trail loci for plant growth of rice in paddy field flooded with salt water. Field Crop Res. 2004, 89, 85-95. [CrossRef]

97. Gregorio, G.B.; Senadhira, D.; Mendoza, R.D.; Manigbas, N.L.; Roxas, J.P.; Guerta, C.Q. Progress in breeding for salinity tolerance and associated abiotic stresses in rice. Field Crops Res. 2002, 76, 91-101. [CrossRef]

98. Suriya-Arunroj, D.; Supapoj, N.; Toojinda, T.; Vanavichit, A. Relative leaf water content as an efficient method for evaluating rice cultivars for tolerance to salt stress. Sci. Asia 2004, 30, 411-415. [CrossRef]

99. Salvi, S.; Tuberosa, R. To clone or not to clone plant QTLs: Present and future challenges. Trends Plant Sci. 2005, 10, 297-304. [CrossRef] [PubMed]

100. Sahi, C.; Singh, A.; Kumar, K.; Blumwald, E.; Grover, A. Salt stress response in rice: Genetics, molecular biology, and comparative genomics. Funct. Integr. Genom. 2006, 6, 263-284. [CrossRef] [PubMed]

101. Marino, R.; Ponnaiah, M.; Krajewski, P.; Frova, C.; Gianfranceschi, L.; Pè, M.E.; Sari-Gorla, M. Addressing drought tolerance in maize by transcriptional profiling and mapping. Mol. Genet. Genom. 2009, 281, 163-179. [CrossRef] [PubMed]

102. Pandit, A.; Rai, V.; Bal, S.; Sinha, S.; Kumar, V.; Chauhan, M.S.; Gautam, R.K.; Singh, R.B.; Sharma, P.C.; Singh, A.K.; et al. Combining QTL mapping and transcriptome profiling of bulked rils for identification of functional polymorphism for salt tolerance genes in rice (Oryza sativa L.). Mol. Genet. Genom. 2010, 284, 121-136. [CrossRef] [PubMed]

103. Ammar, M.H.M.; Pandit, A.; Singh, R.K.; Sameena, S.; Chauhan, M.S.; Singh, A.K.; Sharma, P.C.; Gaikwad, K.; Sharma, T.R.; Mohapatra, T.; et al. Mapping of QTLs controlling $\mathrm{Na}^{+}, \mathrm{K}^{+}$and $\mathrm{Ci}^{-}$ion concentrations in salt tolerant indica rice variety CSR27. J. Plant Biochem. Biotechnol. 2009, 18, 139-150. [CrossRef]

104. Goff, S.A.; Ricke, D.; Lan, T.-H.; Presting, G.; Wang, R.; Dunn, M.; Glazebrook, J.; Sessions, A.; Oeller, P.; Varma, H.; et al. A draft sequence of the rice genome (Oryza sativa L. ssp. Japonica). Science 2002, 296, 92-100. [CrossRef] [PubMed]

105. Thomson, M.J.; Ocampo, D.M.; Egdane, J.; Katimbang, M.; Singh, R.K.; Gregorio, G.; Ismail, A.M. QTL mapping and marker assisted backcrossing for improving salinity tolerance in rice. In Proceedings of the Plant and Animal Genomes XV Conference, San Diago, CA, USA, 13-17 January 2007.

106. Thomson, M.J.; de Ocampo, M.; Egdane, J.; Rahman, M.A.; Sajise, A.G.; Adorada, D.L.; Ismail, A.M. Characterizing the saltol quantitative trait locus for salinity tolerance in rice. Rice 2010, 3, 148-160. [CrossRef]

107. Singh, R.K.; Gopalakrishnan, S.; Singh, V.P.; Prabhu, K.V.; Mohapatra, T.; Singh, N.K.; Sharma, T.R.; Nagarajan, M.; Vinod, K.K.; Singh, D.; et al. Marker assisted selection: A paradigm shift in basmati breeding. Indian J. Genet. 2011, 71, 120-128.

108. Huyen, N.T.L.; Cuc, M.L.; Ismail, A.M.; Ham, H.L. Introgression the salinity tolerance QTLs saltol into AS996, the elite rice variety of vietnam. Am. J. Plant Sci. 2012, 3, 981-987. [CrossRef] 
109. Linh, H.L.; Linh, H.T.; Xuan, D.T.; Ham, H.L.; Ismail, A.M.; Khanh, D.T. Molecular breeding to improve salt tolerance of rice (Oryza sativa L.) in the red river delta of vietnam. Int. J. Plant Genom. 2012, 2012, 949038.

110. Vu, H.T.T.; Le, D.D.; Ismail, A.M.; Le, H.H. Marker-assisted backcrossing (MABC) for improved salinity tolerance in rice (Oryza sativa L.) to cope with climate change in vietnam. Aust. J. Crop Sci. 2012, 6, 1649-1654.

111. Hoque, A.B.M.Z.; Haque, M.A.; Sarker, M.R.A.; Rahman, M.A. Marker-assisted introgression of saltol locus into genetic background of BRRI Dhan-49. Int. J. Biosci. 2015, 6, 71-80.

112. Martinez, V.A.; Hill, W.G.; Knott, S.A. On the use of double haploids for detecting QTL in outbred populations. Heredity 2002, 88, 423-431. [CrossRef] [PubMed]

113. Flowers, T.J. Improving crop salt tolerance. J. Exp. Bot. 2004, 55, 307-319. [CrossRef] [PubMed]

114. Hiei, Y.; Ohta, S.; Komari, T.; Kumashiro, T. Efficient transformation of rice (Oryza sativa L.) mediated by agrobacterium and sequence analysis of the boundaries of the T-DNA. Plant J. 1994, 6, 271-282. [CrossRef] [PubMed]

115. Zhao, F; Zhang, H. Salt and paraquat stress tolerance results from co-expression of the Suaeda salsa glutathione S-transferase and catalase in transgenic rice. Plant Cell Tissue Organ Cult. 2006, 86, 349-358. [CrossRef]

116. Singla-pareek, S.; Yadav, S.K.; Pareek, A.; Reddy, M.K.; Sopory, S.K. Enhancing salt tolerance in a crop plant by overexpression of glyoxalase II. Transgenic Res. 2008, 17, 171-180. [CrossRef] [PubMed]

117. Hoshida, H.; Tanaka, Y.; Hibino, T.; Hayashi, Y.; Tanaka, A.; Takabe, T.; Takabe, T. Enhanced tolerance to salt stress in transgenic rice that overexpresses chloroplast glutamine synthetase. Plant Mol. Biol. 2000, 43, 103-111. [CrossRef] [PubMed]

118. Nagamiya, K.; Motohashi, T.; Nakao, K.; Prodhan, S.H.; Hattori, E.; Hirose, S.; Ozawa, K.; Ohkawa, Y.; Takabe, T.; Takabe, T. Enhancement of salt tolerance in transgenic rice expressing an Escherichia coli catalase gene, katE. Plant Biotechnol. Rep. 2007, 1, 49-55. [CrossRef]

119. Moriwaki, T.; Yamamoto, Y.; Aida, T.; Funahashi, T.; Shishido, T.; Asada, M.; Prodhan, S.H.; Komamine, A.; Motohashi, T. Overexpression of the Escherichia coli catalase gene, katE, enhances tolerance to salinity stress in the transgenic indica rice cultivar, BR5. Plant Biotechnol. Rep. 2008, 2, 41-46. [CrossRef]

120. Tanaka, Y.; Hibino, T.; Hayashi, Y.; Tanaka, A.; Kishitani, S.; Takabe, T.; Yokota, S. Salt tolerance of transgenic rice overexpressing yeast mitochondrial Mn-SOD in chloroplasts. Plant Sci. 1999, 148, 131-138. [CrossRef]

121. Prashanth, S.R.; Sadhasivam, V.; Parida, A. Over expression of cytosolic copper/zinc superoxide dismutase from a mangrove plant Avicennia marina in indica rice var Pusa Basmati-1 confers abiotic stress tolerance. Transgenic Res. 2008, 17, 281-291. [CrossRef] [PubMed]

122. Wu, L.; Fan, Z.; Guo, L.; Li, Y.; Chen, Z.-L.; Qu, L.-J. Over-expression of the bacterial nhaA gene in rice enhances salt and drought tolerance. Plant Sci. 2005, 168, 297-302. [CrossRef]

123. Ohta, M.; Hayashi, Y.; Nakashima, A.; Hamada, A.; Tanaka, A.; Nakamura, T.; Hayakawa, T. Introduction of a Na ${ }^{+} / \mathrm{H}^{+}$antiporter gene from Atriplex gmelini confers salt tolerance to rice. FEBS Lett. 2002, 532, 279-282. [CrossRef]

124. Fukuda, A.; Nakamura, A.; Tagiri, A.; Tanaka, H.; Miyao, A.; Hirochika, H.; Tanaka, Y. Function, intracellular localization and the importance in salt tolerance of a vacuolar $\mathrm{Na}^{+} / \mathrm{H}^{+}$antiporter from rice. Plant Cell Physiol. 2004, 45, 146-159. [CrossRef] [PubMed]

125. Biswas, S.; Razzaque, S.; Elias, S.M.; Amin, U.S.M.; Haque, T.; Islam, S.M.T.; Lisa, L.A.; Naznin, F.; Rasul, N.M.; Seraj, Z.I. Effect of the vacuolar $\mathrm{Na}^{+} / \mathrm{H}^{+}$antiporter transgene in a rice landrace and a commercial rice cultivar after its insertion by crossing. Acta Physiol. Plant. 2014, 37, 1-10. [CrossRef]

126. Chen, H.; An, R.; Tang, J.-H.; Cui, X.-H.; Hao, F.-S.; Chen, J.; Wang, X.-C. Over-expression of a vacuolar $\mathrm{Na}^{+} / \mathrm{H}^{+}$antiporter gene improves salt tolerance in an upland rice. Mol. Breed. 2007, 19, 215-225. [CrossRef]

127. Zhao, F.; Guo, S.; Zhang, H.; Zhao, Y. Expression of yeast SOD2 in transgenic rice results in increased salt tolerance. Plant Sci. 2006, 170, 216-224. [CrossRef]

128. Verma, D.; Singla-Pareek, S.L.; Rajagopal, D.; Reddy, M.K.; Sopory, S.K. Functional validation of a novel isoform of $\mathrm{Na}^{+} / \mathrm{H}^{+}$antiporter from Pennisetum glaucum for enhancing salinity tolerance in rice. J. Biosci. 2007, 32, 621-628. [CrossRef] [PubMed]

129. Obata, T.; Kitamoto, H.K.; Nakamura, A.; Fukuda, A.; Tanaka, Y. Rice shaker potassium channel OsKAT1 confers tolerance to salinity stress on yeast and rice cells. Plant Physiol. 2007, 144, 1978-1985. [CrossRef] [PubMed] 
130. Roy, M.; Wu, R. Arginine decarboxylase transgene expression and analysis of environmental stress tolerance in transgenic rice. Plant Sci. 2001, 160, 869-875. [CrossRef]

131. Sakamoto, A.; Murata, A.N. Metabolic engineering of rice leading to biosynthesis of glycinebetaine and tolerance to salt and cold. Plant Mol. Biol. 1998, 38, 1011-1019. [CrossRef] [PubMed]

132. Mohanty, A.; Kathuria, H.; Ferjani, A.; Sakamoto, A.; Mohanty, P.; Murata, N.; Tyagi, A. Transgenics of an elite indica rice variety Pusa Basmati 1 harbouring the $\operatorname{cod} A$ gene are highly tolerant to salt stress. Theor. Appl. Genet. 2002, 106, 51-57. [PubMed]

133. Su, J.; Hirji, R.; Zhang, L.; He, C.; Selvaraj, G.; Wu, R. Evaluation of the stress-inducible production of choline oxidase in transgenic rice as a strategy for producing the stress-protectant glycine betaine. J. Exp. Bot. 2006, 57, 1129-1135. [CrossRef] [PubMed]

134. Karthikeyan, A.; Pandian, S.K.; Ramesh, M. Transgenic indica rice cv. ADT 43 expressing a $\Delta^{1}$-pyrroline-5-carboxylate synthetase (P5CS) gene from Vigna aconitifolia demonstrates salt tolerance. Plant Cell Tissue Organ Cult. 2011, 107, 383-395. [CrossRef]

135. Kumar, V.; Shriram, V.; Kavi Kishor, P.B.; Jawali, N.; Shitole, M.G. Enhanced proline accumulation and salt stress tolerance of transgenic indica rice by over-expressing P5CSF129A gene. Plant Biotechnol. Rep. 2009, 4, 37-48. [CrossRef]

136. Roy, M.; $\mathrm{Wu}, \mathrm{R}$. Overexpression of S-adenosylmethionine decarboxylase gene in rice increases polyamine level and enhances sodium chloride-stress tolerance. Plant Sci. 2002, 163, 987-992. [CrossRef]

137. Garg, A.K.; Kim, J.-K.; Owens, T.G.; Ranwala, A.P.; Choi, Y.D.; Kochian, L.V.; Wu, R.J. Trehalose accumulation in rice plants confers high tolerance levels to different abiotic stresses. Proc. Natl. Acad. Sci. USA 2002, 99, 15898-15903. [CrossRef] [PubMed]

138. In-Cheol, J.; Se-Jun, O.; Ju-Seok, S.; Won-Bin, C.; Sang Ik, S.; Chung Ho, K.; Youn Shic, K.; Hak-Soo, S.; Choi, Y.D.; Nahm, B.H.; et al. Expression of a bifunctional fusion of the Escherichia coli genes for trehalose-6-phosphate synthase and trehalose-6-phosphate phosphatase in transgenic rice plants increases trehalose accumulation and abiotic stress tolerance without stunting growth. Plant Physiol. 2003, 131, 516-524.

139. Hoang, T.M.L.; Moghaddam, L.; Williams, B.; Khanna, H.; Dale, J.; Mundree, S.G. Development of salinity tolerance in rice by constitutive-overexpression of genes involved in the regulation of programmed cell death. Front. Plant Sci. 2015, 6, 175. [CrossRef] [PubMed]

140. Xu, D.; Duan, X.; Wang, B.; Hong, B.; Ho, T.D.; Wu, R. Expression of a late embryogenesis abundant protein gene, HVA1, from barley confers tolerance to water deficit and salt stress in transgenic rice. Plant Physiol. 1996, 110, 249-257. [CrossRef] [PubMed]

141. Rohila, J.S.; Jain, R.K.; Wu, R. Genetic improvement of basmati rice for salt and drought tolerance by regulated expression of a barley HVA1 cdna. Plant Sci. 2002, 163, 525-532. [CrossRef]

142. Saijo, Y.; Hata, S.; Kyozuka, J.; Shimamoto, K.; Izui, K. Over-expression of a single $\mathrm{Ca}^{2+}$-dependent protein kinase confers both cold and salt/drought tolerance on rice plants. Plant J. 2000, 23, 319-327. [CrossRef] [PubMed]

143. Xiong, L.; Yang, Y. Disease resistance and abiotic stress tolerance in rice are inversely modulated by an abscisic acid-inducible mitogen-activated protein kinase. Plant Cell 2003, 15, 745-759. [CrossRef] [PubMed]

144. Ma, X.; Qian, Q.; Zhu, D. Expression of a calcineurin gene improves salt stress tolerance in transgenic rice. Plant Mol. Biol. 2005, 58, 483-495. [CrossRef] [PubMed]

145. Chen, X.; Guo, Z. Tobacco OPBP1 enhances salt tolerance and disease resistance of transgenic rice. Int. J. Mol. Sci. 2008, 9, 2601-2613. [CrossRef] [PubMed]

146. Se-Jun, O.; Sang Ik, S.; Youn Shic, K.; Hyun-Jun, J.; Kim, S.Y.; Minjeong, K.; Kim, Y.-K.; Nahm, B.H.; Kim, J.-K. Arabidopsis CBF3/DREB1A and $A B F 3$ in transgenic rice increased tolerance to abiotic stress without stunting growth. Plant Physiol. 2005, 138, 341-351.

147. Stam, M.; Mol, J.N.M.; Kooter, J.M. Review article: The silence of genes in transgenic plants. Ann. Bot. 1997, 79, 3-12. [CrossRef]

148. Waterhouse, P.M.; Graham, M.W.; Wang, M.B. Virus resistance and gene silencing in plants can be induced by simultaneous expression of sense and antisense rna. Proc. Natl. Acad. Sci. USA 1998, 95, 13959-13964. [CrossRef] [PubMed] 
149. Wang, M.B.; Waterhouse, P.M. High-efficiency silencing of a beta-glucuronidase gene in rice is correlated with repetitive transgene structure but is independent of DNA methylation. Plant Mol. Biol. 2000, 43, 67-82. [CrossRef] [PubMed]

150. Mette, M.F.; Aufsatz, W.; van der Winden, J.; Matzke, M.A.; Matzke, A.J.M. Transcriptional silencing and promoter methylation triggered by double-stranded rna. EMBO J. 2000, 19, 5194-5201. [CrossRef] [PubMed]

151. Dietz-Pfeilstetter, A. Stability of transgene expression as a challenge for genetic engineering. Plant Sci. 2010, 179, 164-167. [CrossRef]

152. Vaucheret, H. Post-transcriptional small rna pathways in plants: Mechanisms and regulations. Genes Dev. 2006, 20, 759-771. [CrossRef] [PubMed]

153. Rajeevkumar, S.; Anunanthini, P.; Sathishkumar, R. Epigenetic silencing in transgenic plants. Front. Plant Sci. 2015, 6, 693. [CrossRef] [PubMed]

154. Kumpatla, S.P.; Hall, T.C. Recurrent onset of epigenetic silencing in rice harboring a multi-copy transgene. Plant J. 1998, 14, 129-135. [CrossRef] [PubMed]

155. Kanno, T.; Naito, S.; Shimamoto, K. Post-transcriptional gene silencing in cultured rice cells. Plant Cell Physiol. 2000, 41, 321-326. [CrossRef] [PubMed]

156. Miki, D.; Shimamoto, K. De novo DNA methylation induced by sirna targeted to endogenous transcribed sequences is gene-specific and OsMet1-independent in rice. Plant J. 2008, 56, 539-549. [CrossRef] [PubMed]

157. Keren, R.; Miyamoto, S. Reclamation of saline, sodic and boron-affected soils. In Agricultural Salinity Assessment and Management; Tanji, K.K., Wallender, W.W., Eds.; American Society of Civil Engineers: New York, NY, USA, 2011.

158. Bhumbla, D.; Abrol, I. Saline and sodic soils. In Soils and Rice; International Rice Research Institute: Manila, Philippines, 1978; pp. 719-738.

159. Tian, L.; Tan, L.; Liu, F.; Cai, H.; Sun, C. Identification of quantitative trait loci associated with salt tolerance at seedling stage from Oryza rufipogon. J. Genet. Genom. 2011, 38, 593-601. [CrossRef] [PubMed]

160. Wurm, P.A.S.; Campbell, L.C.; Batten, G.D.; Bellairs, S.M. Australian Native Rice: A New Sustainable Wild Food Enterprise; Rural Industries Research and Development Corporation (RIRDC): Barton, Australia, 2012.

161. Cheng, Z.-Q.; Huang, X.-Q.; Zhang, Y.-Z.; Qian, J.; Yang, M.-Z.; Wu, C.-J.; Liu, J.-F. Diversity in the content of some nutritional components in husked seeds of three wild rice species and rice varieties in yunnan province of china. J. Integr. Plant Biol. 2005, 47, 1260-1270. [CrossRef]

162. Garcia-Oliveira, A.L.; Tan, L.; Fu, Y.; Chuanqing, S. Genetic identification of quantitative trait loci for contents of mineral nutrients in rice grain. J. Integr. Plant Biol. 2009, 51, 84-92. [CrossRef] [PubMed]

163. Kissoudis, C.; van de Wiel, C.; Visser, R.G.F.; van der Linden, G. Future-proof crops: Challenges and strategies for climate resilience improvement. Curr. Opin. Plant Biol. 2016, 30, 47-56. [CrossRef] [PubMed]

164. Chen, J.; Huang, Q.; Gao, D.; Wang, J.; Lang, Y.; Liu, T.; Li, B.; Bai, Z.; Luis Goicoechea, J.; Liang, C.; et al. Whole-genome sequencing of Oryza brachyantha reveals mechanisms underlying Oryza genome evolution. Nat. Commun. 2013, 4, 1595. [CrossRef] [PubMed]

165. Zhang, Q.-J.; Zhu, T.; Xia, E.-H.; Shi, C.; Liu, Y.-L.; Zhang, Y.; Liu, Y.; Jiang, W.-K.; Zhao, Y.-J.; Mao, S.-Y. Rapid diversification of five Oryza AA genomes associated with rice adaptation. Proc. Natl. Acad. Sci. USA 2014, 111, E4954-E4962. [CrossRef] [PubMed]

166. Brozynska, M.; Furtado, A.; Henry, R.J. Genomics of crop wild relatives: Expanding the gene pool for crop improvement. Plant Biotechnol. J. 2015, 14, 1070-1085. [CrossRef] [PubMed]

167. Waters, D.L.E.; Nock, C.J.; Ishikawa, R.; Rice, N.; Henry, R.J. Chloroplast genome sequence confirms distinctness of Australian and Asian wild rice. Ecol. Evol. 2012, 2, 211-217. [CrossRef] [PubMed]

168. Brozynska, M.; Omar, E.S.; Furtado, A.; Crayn, D.; Simon, B.; Ishikawa, R.; Henry, R.J. Chloroplast genome of novel rice germplasm identified in northern Australia. Trop. Plant Biol. 2014, 7, 111-120. [CrossRef] [PubMed]

169. Ballini, E.; Berruyer, R.; Morel, J.B.; Lebrun, M.H.; Nottéghem, J.L.; Tharreau, D. Modern elite rice varieties of the 'green revolution' have retained a large introgression from wild rice around the Pi33 rice blast resistance locus. New Phytol. 2007, 175, 340-350. [CrossRef] [PubMed]

170. Chen, L.J.; Lee, D.S.; Song, Z.P.; Suh, H.S.; LU, B.R. Gene flow from cultivated rice (Oryza sativa) to its weedy and wild relatives. Ann. Bot. 2004, 93, 67-73. [CrossRef] [PubMed]

171. Gao, L. Population structure and conservation genetics of wild rice Oryza rufipogon (Poaceae): A region-wide perspective from microsatellite variation. Mol. Ecol. 2004, 13, 1009-1024. [CrossRef] [PubMed] 
172. Pusadee, T.; Jamjod, S.; Rerkasem, B.; Schaal, B.A. Life-history traits and geographical divergence in wild rice (Oryza rufipogon) gene pool in indochina peninsula region. Ann. Appl. Biol. 2016, 168, 52-65. [CrossRef]

173. Song, Z.P.; Lu, B.-R.; Zhu, Y.G.; Chen, J.K. Gene flow from cultivated rice to the wild species Oryza rufipogon under experimental field conditions. New Phytol. 2003, 157, 657-665. [CrossRef]

174. Wurm, P.A.S. A surplus of seeds: High rates of post-dispersal seed predation in a flooded grassland in monsoonal Australia. Aust. J. Ecol. 1998, 23, 385-392. [CrossRef]

175. Sengupta, S.; Majumder, A.L. Porteresia coarctata (Roxb.) tateoka, a wild rice: A potential model for studying salt-stress biology in rice. Plant Cell Environ. 2010, 33, 526-542. [CrossRef] [PubMed]

176. Julia, C.C.; Waters, D.L.E.; Wood, R.H.; Rose, T.J. Morphological characterisation of Australian ex situ wild rice accessions and potential for identifying novel sources of tolerance to phosphorus deficiency. Genet. Resour. Crop Evol. 2016, 63, 327-337. [CrossRef]

177. Atwell, B.J.; Wang, H.; Scafaro, A.P. Could abiotic stress tolerance in wild relatives of rice be used to improve Oryza sativa? Plant Sic. 2013, 215-216, 48-58. [CrossRef] [PubMed]

178. Woodroffe, C.; Chappell, J.; Thom, B. Geomorphological Dynamics and Evolution of the South Alligator Tidal River and Plains, Northern Territory; Australian National University North Australia Research Unit: Darwin, Australia, 1986.

179. Hope, G.S.; Hughes, P.J.; Russell-Smith, J. Geomorphological Fieldwork and the Evolution of the Landscape of Kakadu National Park; Jones, R., Ed.; Archeological Research in Kakadu National Park Australian national Parks and Wildlife Service: Canberra, Australia, 1985; pp. 229-240.

180. Hart, B.; Ottaway, E.; Noller, B. Magela Creek system, Northern Australia. II. Material budget for the floodplain. Mar. Freshw. Res. 1987, 38, 861-876. [CrossRef]

181. White, L.A. Dark cracking clays of the estuarine flood plains of the Northern Territory. In The Properties and Utilisation of Cracking Clay Soils; McGarity, J.W., Hoult, E.H., So, H.B., Eds.; The Properties adn Utiliastion of Cracking Clay Soils. Rev. Rural Sci. 5, 29-35.

182. Wasson, R.J.E. Modern Seditmentation and Late Quarternary Evolution of the Magela Creek Plain; Supervising Scientist for the Alligator Rivers Region: Darwin, Australia, 1992; p. 322.

183. Mollah, W.S. Humpty Doo: Rice in the Northern Territory; Australian National University North Australia Research Unit: Darwin, Australia, 1982.

184. Cockfield, G.; Mushtaq, S.; White, N. Relocation of intensive agriculture to Northern Australia: The case of the rice industry. In Government of Queensland; Technical Report; University of Southern Queensland: Toowoomba, Australia, 2012.

185. Horsch, R.B.; Fry, J.E.; Hoffmann, N.; Eicholz, D.; Rogers, S.G.; Fraley, R.T. A simple and general method for transferring genes into plants. Science 1985, 227, 1229-1231.

186. Jinek, M.; Chylinski, K.; Fonfara, I.; Hauer, M.; Doudna, J.A.; Charpentier, E. A programmable dual-RNA-guided DNA endonuclease in adaptive bacterial immunity. Science 2012, 337, 816-821. [CrossRef] [PubMed]

187. Wang, F.; Wang, C.; Liu, P.; Lei, C.; Hao, W.; Gao, Y.; Liu, Y.-G.; Zhao, K. Enhanced rice blast resistance by CRISPR/Cas9-targeted mutagenesis of the ERF transcription factor gene OSERF922. PLoS ONE 2016, 11, e0154027. [CrossRef] [PubMed]

188. Xu, R.-F.; Li, H.; Qin, R.-Y.; Li, J.; Qiu, C.-H.; Yang, Y.-C.; Ma, H.; Li, L.; Wei, P.-C.; Yang, J.-B. Generation of inheritable and "transgene clean" targeted genome-modified rice in later generations using the CRISPR/Cas9 system. Sci. Rep. 2015, 5, 11491. [CrossRef] [PubMed]

(C) 2016 by the authors; licensee MDPI, Basel, Switzerland. This article is an open access article distributed under the terms and conditions of the Creative Commons Attribution (CC-BY) license (http://creativecommons.org/licenses/by/4.0/). 